\title{
Phylogenetics of Datureae (Solanaceae), including description of the new genus Trompettia and re-circumscription of the tribe
}

\author{
Julia Dupin ${ }^{1 *}$ and Stacey D. Smith ${ }^{1}$ \\ ${ }^{1}$ Department of Ecology and Evolutionary Biology, University of Colorado Boulder, 1800 \\ Colorado Ave, Boulder, CO 80309, USA. \\ * Correspondence author: julia.dupin@ colorado.edu
}

Running head: Phylogenetics of Datureae (Solanaceae)

\begin{abstract}
Datureae G. Don is a tribe in the Solanaceae known for its charismatic large-flowered species (jimsonweeds and angel trumpets). The monophyly of the tribe is well established, but the recent finding that a species previously described in Iochroma (also Solanaceae) belongs in Datureae calls for a reassessment of the tribe's circumscription. Here we estimated the phylogeny of Datureae, including of all of its 18 species, using three nuclear regions, and incorporated fossil information to estimate divergence times. Based on this phylogeny, we reconstructed the evolution of key aspects of reproductive morphology and life history to identify diagnostic features. Our molecular phylogenetic analyses suggest that the diversification of Datureae began roughly ca. 35 $\mathrm{Ma}$, around the beginning of the Andean uplift. Within the tribe, Datura and Brugmansia are monophyletic sister taxa and the misplaced species of Iochroma is sister to the remaining species. Based on our morphological analysis, we describe the latter as a new monotypic genus Trompettia. Ancestral state reconstructions identify diagnostic features for each of the three genera and show a large suite of changes along the Datura branch, including the evolution of erect flowers, capsular fruit and annual life history. Using these features, we formally re-circumscribe Datureae to include all genera and their species and provide a taxonomic key for the tribe.
\end{abstract}

Keywords Andes; Datureae; ITS; leafy; Trompettia; waxy

\section{Introduction}

Building on decades of molecular systematics research in Solanaceae, recent family-level phylogenies include over $40 \%$ of the roughly 2800 species and representatives of nearly all of the recognized genera (Olmstead \& al., 2008; Särkinen \& al., 2013; Ng \& Smith, 2015). Many of the major clades within the family, like the fleshy-fruited solanoids, have been supported as monophyletic since the earliest phylogenetic analyses (Olmstead \& Palmer, 1992; Olmstead \& Sweere, 1994) and are characterized by key differences in chromosome number, embryo shape, and fruit type. These diagnostic features had been previously used in family-level taxonomy (D'Arcy, 1991; Hunziker, 2001), facilitating revision of the traditional classification to create a new, phylogenetically structured classification (Olmstead \& al., 1999, 2008). Given this well-supported phylogenetic classification, recent systematic studies have focused on tackling resolution of smaller clades through more comprehensive species sampling and increased numbers of loci (e.g., Peralta \& Spooner, 2001; Levin \& Miller, 2005; Smith \& Baum, 2006).

The present study focuses on Datureae G. Don, a clade of 18 species sensu Olmstead \& Palmer (1992). Species of Datureae, commonly known as jimsonweeds and angel trumpets, are easily recognizable due to their showy flowers, which are some of the largest in Solanaceae (Fig. 1). Their large flowers have made Datureae popular with horticulturists and gardeners, and indeed, 
humans have been interested in this clade for hundreds of years (Schultes \& Hofmann, 1973). Some species are used by Native American groups due to their hallucinogenic properties (Lockwood, 1973; Schultes \& Hofmann, 1973), a phytochemical signature shared with many other species in the Solanaceae (D'Arcy, 1986). Datureae is also known for its wide geographical distribution. Species of Datura are found in the southwest USA and Mexico, and parts of Central America, while species of Brugmansia are distributed in the Andes and southern portions of the Atlantic forest in Brazil. Moreover, introductions by humans have expanded the range of several species within the Americas and to other continents, and many are found commonly in disturbed areas.

In addition to being a well-supported clade in phylogenetic studies, Datureae and genera within the tribe can be easily distinguished through a suite of morphological features. Hunziker (2001) delimited the tribe Datureae (composed solely of the genera Datura and Brugmansia) by its unusual contorted-conduplicate corolla aestivation, where the lobes are folded lengthwise and twisted to overlap in bud. The two genera, Datura and Brugmansia, are distinguished by fruit type (dry vs. fleshy), fruit shape (fusiform vs. spherical or ovoid), and seed shape (reniform vs. not reniform) (Lockwood, 1973; Hunziker, 2001). Additionally, characters such as seed margin and presence of elaiosomes help define subclades within Datura (Bye \& Sosa, 2013). Recent phylogenetic studies (Smith \& Baum, 2006; Olmstead \& al., 2008) have concluded that Datureae also includes one species previously described in Iochroma, but which possesses the contortedconduplicate corolla aestivation diagnostic of Datureae. Here, we place this species in a new monotypic genus, Trompettia cardenasiana, and revise the characters that delimit the tribe in order to span the three genera (Datura, Brugmansia and Trompettia).

While the monophyly of Datureae is not contested, additional work is needed to clarify relationships within and among genera. For example, the phylogeny of Datura has been examined extensively by Bye and collaborators (e.g. Luna-Cavazos \& al., 2008; Bye \& Sosa, 2013), but its relationship to Brugmansia and now Trompettia is unclear. Moreover, previous phylogenetic studies have included only 3 (or 4) of the 5 recognized species of Brugmansia, leaving relationships within the genus unresolved (Bye \& Sosa, 2013; Särkinen \& al., 2013; Ng \& Smith, 2015). With respect to the placement of Trompettia cardenasiana in Datureae, some analyses recover it as sister to Brugmansia (Särkinen \& al., 2013) while others have resolved it as sister to Datura + Brugmansia (Ng \& Smith, 2015). Finally, the sister group to Datureae remains ambiguous. Whereas some previous studies suggested that Datureae may be sister to the Solanoideae clade containing Solaneae, Capsiceae, and Physaleae (Olmstead \& al., 2008; Ng \& Smith, 2015), others have suggested Datureae is sister to the small South American genus Nicandra (Särkinen \& al., 2013).

In this study, we estimate the phylogeny of Datureae and reconstruct evolution of morphological characters in order to revise genus-level taxonomy and identify diagnostic characters. We use three nuclear markers to infer the placement of Trompettia cardenasiana and incorporate fossil information to estimate divergence times in the tribe. We then reconstruct the evolutionary history of characters used previously in taxonomic investigations of Datureae. Finally, we combine phylogeny and morphological reconstructions to identify characters diagnostic of clades and present a new classification for the tribe. This phylogenetic framework, which is based on complete sampling of species in Datureae, will facilitate future studies of biogeography, genetics, and biochemistry of this economically important group of plants.

\section{Materials and Methods}

\section{Taxon sampling}

In this study, we sampled a total of 26 species: 18 belong to the ingroup and eight representing outgroups (Table 1). The ingroup included all 18 species of Datureae: five Brugmansia, twelve Datura, and one Trompettia. Species sampling in Brugmansia was based on 
Lockwood (1973), who recognized five species: B. arborea, B. aurea, B. sanguinea, B. suaveolens, and $B$. versicolor. We did not sample the many taxa of hybrid origin (e.g. the widespread $B . x$ candida) (reviewed in Hay et al. 2012), nor B. vulcanicola, which was recognized as a species by Hay \& al., 2012) but considered a subspecies of B. sanguinea by Lockwood (1973). Sampling in Datura was based on Bye \& Sosa (2013; note that D. ferox was not included here because it was considered as a synonym of D. quercifolia (as in Symon \& Haegi, 1991). The outgroup sampling spanned species in six tribes within the subfamily Solanoideae (Capsiceae, Juanulloeae, Lycieae, Nicandreae, Physaleae, and Solaneae), which is the subfamily that includes Datureae. We also included one species in the subfamily Nicotianoideae, the sister clade to Solanoideae. Of the 26 species sampled, we included multiple accessions of 16 out of 18 ingroup species. Our final matrix consisted of 50 accessions (Appendix 1).

\section{Data Collection}

We used several sources of leaf material: field collections, living collections from botanical gardens, specimens grown from donated seeds, and herbarium vouchers. We also obtained extracted DNA from collaborators and utilized Genbank sequences when available (Appendix 1). For all leaf samples, we extracted total genomic DNA following a modified 2x CTAB protocol (Doyle, 1987; Smith \& Baum, 2006).

For phylogenetic inference, we used three nuclear regions: the internal transcribed spacers 1 and 2 plus intervening 5.8S region (ITS; White \& al., 1990), the second to ninth exons, and introns, of the granule-bound starch synthase gene region (GBSSI or waxy; Peralta \& Spooner, 2001), and the second and third exons, and second intron, of the LEAFY gene region (lfy; Schultz \& Haughn, 1991). These regions have been useful for species level phylogenetics in other clades in the Solanaceae (e.g., Whitson \& al., 2005; Smith \& Baum, 2006; Tu \& al., 2008). Cytogenetic studies suggest that Datureae are all diploid $(2 \mathrm{n}=24)$ (Hunziker, 2001; Rice $\&$ al., 2015), and thus we did not expect multiple copies for waxy and lfy.

The ITS+5.8S region was amplified and sequenced using four different primers: ITS.leu 1 (Andreasen \& al., 1999), ITS2 and ITS4 (White \& al., 1990), and ITS3B (Baum \& al., 1994). We used the following protocol for $25 \mu \mathrm{L}$ reactions: $2.5 \mu \mathrm{L}$ of 10x PCR Buffer (Qiagen, Valencia, California, USA), $2.5 \mu \mathrm{L}$ of $25 \mathrm{mM} \mathrm{MgCl} 2,1.0 \mu \mathrm{L}$ of Bovine Serum Albumin (BSA), $1.0 \mu \mathrm{L}$ of

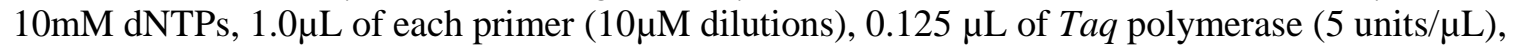
and between 10-100ng of template DNA. We used the following PCR program: $95.0^{\circ} \mathrm{C}$ for 4 min followed by 34 cycles of $95.0^{\circ} \mathrm{C}$ for $2 \mathrm{~min}$ of denaturation, $48.0^{\circ} \mathrm{C}$ for $1 \mathrm{~min}$ of annealing, and $72^{\circ} \mathrm{C}$ for $1 \mathrm{~min}$ of elongation, and finally a final extension of $72^{\circ} \mathrm{C}$ for $5 \mathrm{~min}$.

The waxy region was amplified and sequenced using the primers waxy5', waxy3' and waxyB developed by Peralta \& Spooner (2001), and waxyF41, waxyF420 and waxyR991 developed by Smith \& Baum (2006). The protocol for waxy is similar to that of ITS+5.8S except we used only $2.0 \mu \mathrm{L}$ of $25 \mathrm{mM} \mathrm{MgCl} 2$ and added $1.0 \mu \mathrm{L}$ of Q solution (Qiagen). We used the following PCR program: $95.0^{\circ} \mathrm{C}$ for $4 \mathrm{~min}$, then 35 cycles of $95.0^{\circ} \mathrm{C}$ for $45 \mathrm{~s}$ of denaturation, $52.0^{\circ} \mathrm{C}$ for $1 \mathrm{~min}$ of annealing, $72^{\circ} \mathrm{C}$ for $2 \mathrm{~min}$ of elongation, and finally a final extension of $72^{\circ} \mathrm{C}$ for $5 \mathrm{~min}$.

The lfy region was amplified and sequenced using primers developed for this study (Appendix 2). To accomplish this, we used transcriptome sequences for different Datura species as reference to design primers (transcriptome sequences available through the Medicinal Plants Transcriptome project, http://apps.pharmacy.uic.edu/depts/pcrps/MedTranscriptomePlants). The PCR protocol for lfy was the same as that for waxy, but we adjusted the annealing temperature depending on the primer pair used.

All PCR products were sequenced in both directions using ACGT Inc. sequencing services (Wheeling, Illinois, USA). The resulting sequences were manually edited in 4Peaks v1.7 and 
assembled into contigs using the MUSCLE online alignment tool (Edgar, 2004) and secondarily edited in Mesquite v3.10 (Maddison \& Maddison, 2017).

We used the g1 statistic (Hillis \& Huelsenbeck, 1992) to assess phylogenetic signal in our datasets. This parsimony-based statistic measures the skew in the distribution of tree lengths for a set of random trees using the observed data; datasets with phylogenetic signal are expected to be left-skewed, with an excess of short (more-parsimonious) trees. For each of our datasets (ITS+5.8S, lfy and waxy), we estimated g1 using 10,000 randomly-drawn trees in PAUP* v4.0a150 (Swofford, 2003) with significance levels based on Hillis \& Huelsenbeck (1992).

\section{Phylogenetic inference}

We conducted three sets of phylogenetic analyses: maximum parsimony analyses of individual and combined datasets to yield initial phylogenetic hypotheses and assess congruence between datasets; a Bayesian species tree analysis with Datura-only sampling to assess gene treespecies tree conflict; and a Bayesian divergence time analysis on the combined dataset using two sets of fossils. Although technically the last two Bayesian analyses could have been combined into a single analysis, we observed poor convergence when attempting to simultaneously estimate divergence times as well as coalescent parameters of the species tree. This poor convergence may be due to the large number of parameters as well as the imbalance in numbers of individuals sampled per species (e.g. multiple for most ingroup taxa, but just one for all of the outgroups, Appendix 1). By dividing the analyses into two, we were able to achieve convergence of a species tree analysis for Datura with multiple samples per species and also convergence of a dating time analysis with all species but only one individual per species. Below we describe each of the analyses in turn.

For the initial parsimony analyses, we built $50 \%$ majority rule consensus trees for each nuclear region separately using PAUP* v4.0a150 (Swofford, 2003). Here, species with multiple individuals (16 of the 18 ingroup taxa) were represented by a consensus sequence. We chose this approach because intraspecific variation in the ingroup taxa was substantially lower than interspecific variation (average pairwise difference of 0.004 across sequences within species versus 0.07 across species). Clade support was estimated through heuristic search with 1000 bootstrap replicates, each with 10 random sequence additions and tree-bisection-reconnection (TBR) branch swapping. For ITS+5.8S and waxy, the consensus tree included all 26 taxa. For lfy, it included 13 ingroup taxa. This latter reduction was due to a lack of complete lfy sequences for five species (Brugmansia suaveolens, B. versicolor, Datura lanosa, D. metel, D. reburra) as well as difficulty aligning lfy sequences outside of Datureae given high variation in the intron. Next, we compared consensus trees for the three nuclear regions to identify cases of hard incongruence (conflicting clades with bootstrap support (BS) greater than or equal to 70\%; Mason-Gamer \& Kellogg, 1996). This assessment was done in two steps: first, via a comparison between the consensus trees of ITS+5.8S and waxy that included all 26 taxa, and second via a comparison between all three region consensus trees but with a reduced dataset of 13 taxa to match all the species included in the lfy consensus tree.

Given minor instances of hard incongruence among gene trees for Datura (see results), we estimated the species relationships within this genus using the combined dataset and methods that accommodate discordance. For this Datura-only analysis, we implemented starBEAST2 (Ogilvie \& Drummond, 2016), an extension of BEAST2 (Drummond \& al., 2012; Bouckaert \& al., 2014) that facilitates joint inference of a species tree topology and gene trees from multiple genes while allowing for potential conflicts in the estimated gene topologies. We included multiple samples for most species, with the exception of $D$. arenicola and $D$. discolor for which we had only one sample each. Within starBEAST, we created 5 partitions: ITS+5.8S, lfy.exons, lfy.intron, waxy.exons and waxy.introns. For the lfy and waxy regions, we considered exons and introns as separate partitions to 
account for potential variation in rates and patterns of substitution among sites. The same was not done for ITS $+5.8 S$ given the small length of the $5.8 S$ coding region $(\sim 150 \mathrm{bp})$. Although introns and exons were input separately, we linked the molecular clocks and estimated linked trees for exons and introns belonging to the same region, as they are expected to share the same history. The substitution models for each partition were determined using Likelihood Ratio Tests (LRTs), in which the following models were considered: JC, K81, HKY85, HKY85 + GTR, GTR $+\Gamma$, and GTR $+\Gamma+$ I. The best fitting likelihood models for each partition are presented in Table 2. starBEAST2 also requires priors for the individual gene trees, along with a prior for the species tree. For the gene trees, under "multispecies coalescent models", we chose the 'Linear with constant root populations' option that allows population size changes over time through the act of smooth (i.e., not abrupt) changes. We used an uncorrelated lognormal clock model to describe the branch-specific substitution rates for all partitions (Drummond \& al., 2006). Finally, for our species tree, we specified a Birth-Death prior.

After assessing congruence and addressing the conflicts within Datura, we estimated the phylogeny of Datureae and divergence times within the lineage using a Bayesian approach implemented in BEAST2 (Bouckaert \& al., 2014). We incorporated the starBEAST2 results (see below) into this divergence time analysis by constraining two Datura clades with high posterior probability (>95\%) to be monophyletic (1: D. arenicola, D. discolor, D. quercifolia and $D$. stramonium L., and 2: D. inoxia, D. kymatocarpa, D. metel, D. lanosa, D. leichhardtii ssp. pruinosa, D. reburra and D. wrightii). We used a consensus sequence to represent each taxon for the divergence time analysis. We input the individual alignments in the same fashion as for starBEAST2, including the same substitution models and linkage of molecular clock and trees for exons and introns belonging to the same region. We used an uncorrelated, lognormal relaxed clock model to describe the branch-specific substitution rates (Drummond \& al., 2006) and a birth-death tree prior. We carried out three MCMC runs for 35 million generations each, sampling every 1000 generations. Convergence and stationarity of the parameters were assessed using Tracer v1.6 (Rambaut \& al., 2014) and LogCombiner (part of the BEAST2 package), targeting minimum effective sample sizes (ESS) for all variables of at least 200. Finally, we used TreeAnnotator (part of the BEAST2 package), discarding a burn-in of the first $25 \%$ of trees, to construct a maximum clade credibility (MCC) tree that included the median value for node ages, 95\% highest posterior density (HPD) of divergence times, and posterior probabilities (pp) for all nodes.

For fossil calibrations, we incorporated fossil ages as node priors with log-normal distributions. The first fossil we used is a macrofossil (seed) identified as Datura cf. stramonium by Velichkevich \& Zastawniak (2003). Based on its reniform shape, its thick testa of dark coloration with numerous, irregular, shallow pits, a small incision, and lack of a convex margin triple-ridge, Velichkevich \& Zastawniak (2003) assigned this fossil to the crown clade formed by $D$. stramonium and D. quercifolia. Since the mentioned study was published, a new species of Datura has been described, D. arenicola (Bye \& Sosa, 2013), whose seeds also resemble the macrofossil in all morphological aspects listed above except that it has a larger incision. Because $D$. arenicola does not form a clade with $D$. stramonium and/or D. quercifolia, we chose to use the fossil age, between 3.6 and 2.6 million years ago (Ma), as a minimum age reference for the crown age of the entire Datura genus. The second fossil calibration was a set of macrofossils recently described as a Physalis species (Wilf \& al., 2017). The macrofossils (fruiting calyces) have an estimated minimum age of 52.2 Ma. Even though the fossils are assigned to Physalis, we here used it as a prior to constrain the Solanoideae node for two reasons. First, Physalis is paraphyletic (Olmstead \& al., 2008; Särkinen \& al., 2013) and overall the phylogeny of Physaleae, which includes many other taxa with similarly inflated calyces, is poorly resolved (Whitson \& al., 2005; Ng \& Smith, 2015). Second, the primary character used to identify the fossils as Physalis - the presence of an inflated calyx - may be pleisiomorphic in Solanoideae. Indeed, this character occurs in multiple solanoid 
lineages, including Hyoscyameae, Juanulloae, Nicandreae, Solaneae and Withaninae (He \& al., 2004; Hu \& Saedler, 2007).

\section{Character Evolution within Datureae}

We estimated the history of character changes for seven traits: flower orientation (pendant vs. erect), flower pigmentation (presence of anthocyanins vs. absence), fruit type (fleshy vs. dry) and fruit shape (fusiform vs. round/ovoid), seed elaiosomes (presence vs. absence), seed margin type (single ridge vs. triple ridge margin), and life history (perennial vs. annual/bi-annual). For the life history trait in particular, we acknowledge that this trait is usually part of a spectrum between short and long lived species. Here we score it as dichotomous trait based on records such as herbarium labels and descriptions in floras and taxonomic studies. Said records consistently describe Datura species as short lived species, many regularly referred as annuals, and Brugmansia ones as long lived plants whose lifespan goes from several years to a couple of decades. We defined this set of characters based on significance to Solanaceae (Hunziker, 2001) and Datureae (Lockwood, 1973; Bye \& Sosa, 2013) taxonomy. We scored character states based on species descriptions and observations of living and herbarium collections.

For ancestral state reconstructions, we used a pruned version of the MCC tree estimated here. This pruned tree included all Datureae species and the inferred sister group, Nicandra. We carried out these analyses using the $r$ packages 'ape' v4.1 (Paradis \& al., 2004) and 'phytools' v0.564 (Revell, 2011) in R (R Core Team, 2015). For each character separately, we first compared models that assumed equal rates of transition between character states or different rates (using the function ace in 'ape', Paradis \& al. (2004)). The likelihood of each model was estimated and compared using a likelihood ratio test. Once we identified the best model, we estimated the history of each character using the function make.simmap in 'phytools' v0.5-64 (Revell, 2011). This function uses stochastic character mapping (Nielsen, 2002; Huelsenbeck \& al., 2003) to sample states at ancestral nodes and build possible histories for a given character. For each of our characters, we simulated 100 histories and summarized the results at each node to give the relative posterior probability at each state.

\section{Results}

\section{Assessment of congruence among datasets}

Our results suggest little incongruence among the three nuclear regions. The individual consensus trees showed no conflict among the datasets regarding the position of Trompettia cardenasiana, the monophyly of Datura, and of Brugmansia, or the sister group to Datureae. Nonetheless, there was variation in resolution and phylogenetic signal that the individual datasets provided (see Fig. 2 for individual consensus trees and Table 2 for summary statistics). The only instance of hard incongruence (BS $>70 \%$ ) was between ITS $+5.8 S$ and waxy, which yielded conflicting information regarding the position of two clades: (1) Datura stramonium and $D$. quercifolia and (2) D. kymatocarpa and D. leichhardtii ssp. pruinosa. In ITS+5.8S these four taxa form a clade while in waxy they do not (Fig. 2). Our Datura-only starBEAST2 analysis, which estimated the species tree topology while allowing for gene tree conflict, supported the waxy topology where D. stramonium, D. quercifolia, D. kymatocarpa and D. leichhardtii ssp. pruinosa do not form a clade (Appendix 3).

\section{Phylogenetic relationships and divergence times in Datureae}

Our Bayesian analysis of the combined dataset yielded a MCC tree in which Datura and Brugmansia were resolved as monophyletic with strong support (posterior probability [pp] of 1.0), with Trompettia cardenasiana as sister to the two (Fig. 3; files for MCC tree and alignment matrix 
were deposited at TreeBase, http://purl.org/phylo/treebase/phylows/study/TB2:S22050). The sister group to the tribe was well supported as Nicandra physalodes (0.97 pp). Our analyses resolved two major clades within Datura (Fig. 3). The first clade comprised D. wrightii, D. lanosa, D. metel, D. reburra, D. kymatocarpa, D. inoxia, and D. leichhardtii ssp. pruinosa while the second clade was formed by $D$. stramonium, $D$. quercifolia, $D$. discolor, and $D$. arenicola. Datura ceratocaula was well supported as sister to all other Datura species. These relationships differ from those of Bye \& Sosa (2013) except in the position of $D$. ceratocaula as sister to the rest. Only two nodes within Datura were marked by low pp values $(0.5$ and 0.52 ; Fig. 3$)$. We attribute these to the lack of variation in ITS+5.8S and waxy sequences for many species in Datura along with the missing lfy sequences for three species in Datura (D. lanosa, D. metel, and D. reburra). Within Brugmansia, our analyses resolved two clades with strong support, the first comprising $B$. arborea and $B$. sanguinea and the other containing $B$. suaveolens and $B$. versicolor as sister species, with $B$. aurea sister to the pair (Fig. 3).

The divergence time estimates placed the origin of subfamily Solanoideae in the Eocene (ca. $54 \mathrm{Ma}$ ) and early stages of diversification of Datureae in the late Eocene to early Oligocene (Fig. 3; see Appendix 4 for divergence dates with confidence intervals). The median age of the crown Datureae, and Trompettia, was estimated as 34.7 Ma (95\% HPD interval: 23.8-46.8 Ma). The split between Datura and Brugmansia was estimated as 28.5 Ma (95\% HPD interval: 18.7-39.2 Ma), during the middle Oligocene (Fig. 3). Major splits within these two genera were inferred to occur during the Miocene (between 10 and 18 Ma; Fig. 3).

\section{Character evolution}

Many of the characters analyzed in this study were diagnostic for clades or subclades of Datureae and thus may be useful for classification (Fig. 4). Flower orientation, fruit type and life history characters distinguish Datura from Brugmansia and Trompettia. These three traits show the same pattern where a single transition is estimated along the Datura stem lineage (Fig. 4). The remaining four characters (fruit shape, seed margin type, seed elaiosomes, and flower pigmentation) vary within the genera, and most are associated with particular subclades. For example, fusiform fruit shape is diagnostic for the B. versicolor and B. suaveolens lineage, with one change inferred along their stem branch. Within Datura, seed margins with a triple ridge are present only in the clade containing D. metel, D. wrightii, D. lanosa, D. reburra, D. kymatocarpa, and D. inoxia, although this state has apparently been lost in $D$. kymatocarpa. In addition, the clade comprising $D$. wrightii and D. lanosa (Fig. 4) is the only lineage of Datura that lacks elaiosomes. Compared to these characters, flower pigmentation (presence of anthocyanins vs. absence) was highly homoplastic across the phylogeny, and thus is not likely to be of taxonomic utility (Fig. 4).

\section{Discussion}

Our molecular results support a monophyletic Datureae formed by three genera: Datura and Brugmansia, which are sister taxa, and the monotypic genus Trompettia, which is sister to the other genera. The placement of Trompettia is corroborated by our comparison of morphological features among the genera. Divergence time analyses suggest that Datureae started diversifying around 35 $\mathrm{Ma}$, likely in dry areas in the central and southern Andes. Finally, our results show that a large number of major morphological changes (e.g., transition from fleshy to dry fruits and from pendant to erect flowers) within the tribe happened along the branch giving rise to Datura.

\section{Phylogenetic Relationships}


Our study supports the placement of Datureae within subfamily Solanoideae and recovered most of the major relationships among solanoids identified in previous studies. As in Olmstead \& al., 2008 and Särkinen \& al. (2013), the lineage containing Lycium is sister to all other species in Solanoideae, and Physalis plus Capsicum form a monophyletic group (Fig. 3). The position of some of the outgroup taxa (Mandragora, Juanulloa) differ from previous studies, but do not conflict prior results due to the low support for those nodes. Thus, our analyses do not present any instances of hard conflict in terms of the outgroup taxa compared with other recent phylogenies (Olmstead \& al., 2008; Särkinen \& al., 2013).

We also recovered Nicandra as the sister clade to the monophyletic Datureae, as in Särkinen \& al., 2013. Like Trompettia and some species of Brugmansia, Nicandra has an Andean distribution, with its three described species occurring from Peru to northern Argentina (Hunziker, 2001; Leiva Gonzalez \& Pereyra Villanueva, 2007; Leiva Gonzalez, 2010). The genus has many unique features (a 3 to 5-carpellate gynoecium, auriculate calyx segments, imbricate-plicate corolla aestivation) and has thus been placed in its own tribe, Nicandreae (Wettstein, 1895). Beyond those unique characters, Nicandra shares many morphological features with Datureae but also with other Solanoideae clades. Additional studies may identify morphological synapomorphies that unite Nicandra with Datureae specifically, and thus support our molecular phylogenetic results.

Within Datureae, our analyses confirm the monophyly of each genus and places Trompettia as sister to the remaining two. The monophyly of Datura, and Brugmansia, once disputed based on morphological characters (Persoon, 1805; Bernhardi, 1833; Safford, 1921; Barclay, 1959), has been supported in multiple studies (Bye \& Sosa, 2013; Särkinen \& al., 2013; Ng \& Smith, 2015) and is corroborated here with comprehensive species sampling. By contrast, the position of Trompettia (included under the name Iochroma cardenasianum), has varied across analyses, sometimes appearing as sister to Brugmansia (Särkinen \& al., 2013). Our molecular phylogenetic analysis confidently places Trompettia within the tribe as sister to both Datura and Brugmansia, consistent with Ng \& Smith (2015). This placement combined with the unique combination of morphological features prompts our establishment of a new genus to accommodate this monotypic lineage (see Taxonomic Innovations).

While many of the clades that we inferred mirror those in prior studies, relationships within Datura differ markedly from those presented in previous analyses. Bye \& Sosa (2013) also sampled all species of Datura and defined two major sections within Datura: Dutra and Datura. Section Datura sensu Bye \& Sosa (2013) contains D. arenicola, D. discolor, D. ferox, D. quercifolia, D. kymatocarpa, D. leichhardtii, and D. stramonium while section Dutra comprises D. inoxia, D. lanosa, D. metel, D. reburra, and D. wrightii. Our study failed to support monophyly of these two sections given that $D$. kymatocarpa, and D. leichhardtii are more closely related to members of section Dutra than the remaining species of section Datura (Fig. 3). These different outcomes likely relate to the markers used (plastid DNA in Bye \& Sosa (2013); nuclear in the present study) and may reflect introgression or incomplete lineage sorting (Soltis \& Kuzoff, 1995; Wendel \& Doyle, 1998). Nonetheless, both our study and that of Bye \& Sosa (2013) recovered D. ceratocaula as sister to all other species in the genus, suggesting concordance along some branches. Future phylogenetic work in Datura would benefit from more extensive sampling within species and expanded set of markers to resolve the poorly supported regions of the phylogeny (Fig. 3) and to provide a robust test for reticulation during the diversification of the genus (e.g., Solís-Lemus \& Ané, 2016).

Although this study represents the first comprehensive molecular phylogenetic analysis of Brugmansia, relationships within the genus recovered here were similar to those proposed by Lockwood (1973) in his monographic treatment. Based on morphology, geographical distribution, and crossing experiments, Lockwood (1973) and Hay \& al. (2012) divided the genus into two informal groups: B. suaveolens and B. versicolor from the Amazonian and Ecuadorian lowlands, 
and B. arborea, B. sanguinea, and B. aurea from high elevations in the northern and central Andes. The concordance of our phylogeny with the distribution of the taxa suggests that geographic isolation may have played a key role in the divergence of these lineages.

\section{Dating the Diversification of Datureae}

Divergence time estimates within Solanaceae have been challenging because of the scarcity of fossils that can be confidently assigned to the family or clades within it (Särkinen \& al., 2013; Millan \& Crepet, 2014). Here, we incorporate recently described macrofossils of fruiting calyces (Wilf \& al., 2017) into divergence time analyses and recover dates that are older than those estimated in previous studies (Särkinen \& al., 2013; De-Silva \& al., 2017). Although we conservatively assigned these fruit fossils to the Solanoideae stem lineage, they are roughly twice as old as any of the fossils previously used to calibrate this node (52.2 Ma vs. $28 \mathrm{Ma}$, Särkinen \& al., 2013). With our two calibration points (the Datura seed fossil of 3.6 Ma and the fruiting calyces macrofossils of 52.2 Ma), we estimate a crown age for Datureae of $34.7 \mathrm{Ma}$ (95\% HPD interval: 23.8-46.8 Ma; Fig. 3). This compares to 8.5 Ma (95\% HPD interval: 5.5-11.7 Ma) in Särkinen \& al. (2013) and 11.5 Ma (95\% HPD interval: 6.8-17.4 Ma) Ma in De-Silva \& al. (2017) who used secondary calibrations from an angiosperm wide analysis (Magallón \& al., 2015).

Although divergence times in Solanaceae are likely to remain contentious until more fossils are described, the dates we estimate for cladogenetic events in Datureae are well aligned with major changes in the global climate and geological events in the Americas. The Andean uplift began roughly $45 \mathrm{Ma}$ in the southern portions of the mountain chain, with important uplift and erosion data from regions between Patagonia and the Peruvian and Bolivian Andes supporting that date estimate (Sébrier \& al., 1988; Ege \& al., 2007; Graham, 2009; Blandin \& Purser, 2013). Northern and central regions formed later between late Eocene and upper Miocene, roughly 15 and $35 \mathrm{Ma}$, respectively (Blandin \& Purser, 2013). Based on the current distribution of Trompettia, Brugmansia and the Datureae's sister group estimated here, Nicandra, a Central Andes (roughly Peru and Bolivia today) origin for Datureae is likely. Furthermore, given that we estimated the tribe to have originated around $35 \mathrm{Ma}$, this origin date places the diversification of Datureae starting at a similar time period as the uplift in the Central Andes. Besides the geological modifications, the rise of the Andes created new habitats and new ecological opportunities that fostered speciation (Pennington \& al., 2010; Särkinen \& al., 2013).

The diversification of Brugmansia is aligned with the appearance of some of those new habitats, in this case, the montane ones in the Northern Andes. During the Miocene (between 23 and $5 \mathrm{Ma}$ ), while the Andean uplift continued, a geological feature kept the Northern Andes and the Central Andes isolated. This corridor of ocean intrusion named "West Andean Portal" ("WAP", Antonelli \& al., 2009) in Ecuador ceased to exist ca. 12 Ma when the region experienced geological uplift (Antonelli \& al., 2009; Blandin \& Purser, 2013). This uplift closed the gap between Central and Northern Andes and allowed migration of species between the two regions, possibly including Brugmansia species. The B. aurea lineage, native from Colombia and parts of Ecuador (Lockwood, 1973; Hay \& al., 2012) split from its sister clade (B. suaveolens $+B$. versisolor) approximately 9 Ma. Next, the B. versicolor lineage, native to lowlands of central Ecuador (Lockwood, 1973; Hay \& al., 2012), split from the $B$. suaveolens lineage roughly $6 \mathrm{Ma}$. These dates can corroborate the idea that the tribe and the Brugmansia genus originated in regions of the in Central Andes, and only later during their diversification, species were able to colonize the Northern Andes.

\section{Character Evolution}

The evolution of Datureae is marked by major transitions in morphology and life history, which may be driven by differences in geographical distribution and habitat (Fig. 4). The woody, perennial taxa (Brugmansia spp. and Trompettia) are native to tropical regions of the Americas, 
while the herbaceous, annual taxa (Datura spp.) are distributed in dry, seasonal areas of Mexico and the southwestern United States, and parts of northern Central America. Correlated shifts in life history and habitat seasonality have been observed in many other plants groups, such as Onagraceae and Asteraceae (Evans \& al., 2005; Cruz-Mazo \& al., 2009). Annual habit likely evolves as an adaptive response to seasonal or unpredictable environments, where the shift represents a defense against conditions that would adversely affect adult perennial plants (Friedman \& Rubin, 2015).

These shifts in life history and habit across Datureae have been accompanied by changes in floral traits and pollination systems. For example, the shrubby Brugmansia and Trompettia produce pendant flowers while those of low-growing Datura are largely erect. The showy flowers of $B$. arborea, B. aurea, B. suaveolens and B. versicolor release their scent at night and are visited by moths and bats while the unscented flowers of $B$. sanguinea are more frequently visited by hummingbirds (Lockwood, 1973; Knudsen \& Tollsten, 1993; Weiss, 1995; Hay \& al., 2012). By contrast, the erect or semi-erect scented flowers of Datura are principally pollinated by hawkmoths (Raguso \& al., 2003; Bronstein \& al., 2009), which are common floral visitors in the open, dry areas that characterize the native range of the genus. Although little is known about the pollination of Trompettia, its small unscented yellow flowers could be visited by a wide range of animals.

In addition to these changes in floral morphology, Datureae have diversified in fruit and seed morphology. While Brugmansia and Trompettia retain the ancestral state of fleshy fruits, Datura has evolved a capsular fruit form. The animal dispersers of Brugmansia and Trompettia fruits or seeds are unknown (Lockwood, 1973; Hay \& al., 2012) although their corky seed coat makes water a possible secondary vector. The presence of elaiosomes on the seeds of many Datura species suggests dispersal by ants, who feed on these protein- and lipid-rich bodies (Marussich, 2006). For example, two Sonoran desert species of harvester ants (Veromessor pergandei and Pogonomyrmex californicus) forage for seeds of $D$. discolor and transport the seeds back to their nest to remove and consume the elaiosomes (O'Dowd \& Hay, 1980). Seeds can be transported by ants up to $40 \mathrm{~m}$ from the mother plant and further dispersed by other forces, like wind and water (O'Dowd \& Hay, 1980). Datura is the only genus of Solanaceae known to produce elaiosomes, but across angiosperms, these structures have evolved at least 100 times, often in seasonal, Northern Hemisphere taxa (Lengyel \& al., 2009, 2010).

\section{Taxonomic Implications}

The separation of Datura and Brugmansia has long been a topic of debate in the taxonomic literature. Datura was described in 1753 by Linnaeus based on the type species, D. stramonium. Subsequently, Persoon (1805) transferred D. arborea to a new genus, Brugmansia, based on its persistent calyx with a lateral split, and non-spiny, bilocular fruits. This separation was subsequently rejected by many others (e.g., Bernhardi, 1833; Safford, 1921; Barclay, 1959) because some of the diagnostic characters could also be found in one Datura species, D. ceratocaula. Specifically, D. ceratocaula produces fruits with smooth surfaces that do not completely dry before dehiscing and a fugacious calyx once fruit development initiates. This combination of characters is intermediate between species of Datura, which have dry, spiny, dehiscent fruits without persistent calyces and species of Brugmansia, which for the most part have fleshy, smooth, indehiscent fruits with persistent calyces. Hence, D. ceratocaula was seen by Bernhardi (1833), Safford (1921), and Barclay (1959) as an irrevocable link between Datura and Brugmansia, justifying the argument to maintain all the species as belonging to a single genus. Only with the work of Lockwood (1973) did the recognition of the generic rank of Brugmansia become more popular. In addition to their many differences in habit, longevity, habitat, fruit type, flower position, and seed morphology (Table 3), species in the two genera have proved extremely difficult to cross artificially (Carson, 1945; Joshi, 1949). The position of D. ceratocaula as sister to all other Datura species (see Fig. 3; see also Bye \& Sosa, 2013) reaffirms that this species should be treated in Datura. Its unique combination of 
characters may represent changes specific to its lineage and/or retention of ancestral or intermediate states (e.g., smooth fruits, incomplete dehiscence).

Given the distinctiveness of Trompettia, we propose to recognize it as a new genus in Datureae. When first described (Hunziker, 1977), T. cardenasiana was placed in Iochroma due to morphological similarities with other species in the Iochrominae such as size of the flower, its infundibuliform (trumpet-shaped) corolla, and its geographical distribution. However, the lack of flower buds, fruits, and seeds on the type specimen prevented comprehensive comparison of this species to other species in Iochroma and other genera. Even though T. cardenasiana has fruits that are small, round berries, which are common in Iochrominae and several other clades in Solanoideae, the seeds are tetrahedral and have a thin corky seed coat, very similar to those of Brugmansia. Also, the small trumpet-shaped flowers of $T$. cardenasiana have distinctly flared corolla lobes that are arranged in a contorted-conduplicate fashion in the bud, a character diagnostic of Datureae. These features support a close relationship of Trompettia to remaining Datureae, as further emphasized by our molecular data. Trompettia can, however, easily be distinguished from Datura and Brugmansia by several features, in particular the size of flowers and fruit and the distinct form of the fruiting calyx (Table 3). Additionally, T. cardenasiana has a very restricted distribution in the southern parts of Bolivia, which does not overlap with the native ranges of species of Datura or Brugmansia in the north and central Andes, Central America, and southern parts of North America.

Below, we describe Trompettia and make the new combination. We then formally recircumscribe Datureae to include all three genera and their species. Finally, we provide a taxonomic key to identify species of Datureae worldwide.

\section{Taxonomic Innovations}

Trompettia J. Dupin, gen. nov. - Type: Trompettia cardenasiana (Hunz.) J. Dupin (三 Iochroma cardenasianum Hunz.).

Perennial shrubs with simple and alternate leaves. Flowers solitary in leaf axils, pedicellate, and pendant. Corollas infundibuliform. Stamens five, filaments adnate to basal portion of corolla tube, included entirely within the corolla. Anthers basifixed, dehiscence latrorse. Ovaries superior, bilocular, surrounded by a nectary at the base, the styles included within corollas. Fruits baccate. Seeds tetrahedral, embryos coiled.

Etymology: The generic name Trompettia from the French trompette, diminutive of trompe (horn), alludes to the type species' flowers that are shaped like small trumpets.

Trompettia cardenasiana (Hunz.) J. Dupin, comb. nov. $\equiv$ Iochroma cardenasianum Hunz. in Kurtziana 10: 21. 1977. Holotype: Bolivia, Dpto. Potosí: Cotagaita, 3000m alt., XII 1932, M. Cardenas 323, (US barcode US-00385907!) (Fig.5).

Woody shrubs to $2 \mathrm{~m}$ tall. Stems erect but arching towards apices, many of these becoming spiny, older portions glabrous, becoming pubescent towards younger portions of stem, trichomes simple, $<0.25 \mathrm{~mm}$, the internodes $4-35 \mathrm{~mm}$ long. Spines 3-8 cm, $0.2-0.3 \mathrm{~mm}$ in diameter at base. Leaves borne in clusters on very short shoots (these $<1 \mathrm{~mm}$ long), subtended by dense protrusions of trichomes (Appendix 5), on short petioles to 5mm long, these pubescent with short eglandular trichomes or glabrous, the blades simple, alternate, narrowly obelliptic to narrowly elliptic, 20-50 x 3-10 mm, (2-)4.7 to 7.5 times longer than wide, the bases attenuate, the apices broadly acute to 
obtuse, the margins entire, both surfaces covered by glandular trichomes (these seeming to result in black spots on pressed specimens) with occasional sparse simple trichomes along midrib of abaxial surface. Flowers solitary in leaf axils, on pedicels to $6 \mathrm{~mm}$ long, pubescent with eglandular trichomes, pendant. Calyces 9-12 mm long at anthesis, the tubes 5-6 x 4-5 mm, light green, the lobes subulate, 5-6 mm long, pubescent adaxially, slightly accrescent during fruit maturation and eventually splitting along longitudinal axis to expose mature fruit. Corollas infundibuliform (these more tubular just before anthesis), 30-35 $\mathrm{mm}$ long including lobes and 12-17 $\mathrm{mm}$ wide at the mouth, yellow (paler at base, becoming more vibrant towards apex), the lobes $2-4$ x $7-10 \mathrm{~mm}$, primary lobe veins extending into acuminate tip, external surfaces pubescent with uniformly distributed short, eglandular trichomes. Stamens 5, the filaments $22-25 \mathrm{~mm}$, adnate to the basal 5-8 $\mathrm{mm}$ of the corolla tube, free portions $17-19 \mathrm{~mm}$, included within corolla, pubescent only along the adnate portion. Anthers 3-4 x 2-2.5 mm, basifixed, dehiscence latrorse, glabrous. Ovary superior, bilocular, surrounded by dark red nectary at base, glabrous, the styles $27-29 \mathrm{~mm}$, included within the corolla. Fruits berry, round, 5-10 mm wide, immature fruits green turning dark brown in pressed specimens. Seeds tetrahedral, 3-4 mm, brown to dark brown, ca. 10-20 per fruit, embryo coiled.

Trompettia cardenasiana is similar to Brugmansia species in having both pendant flowers and fleshy fruits. It is, however, readily distinguishable by its much smaller flowers, small, narrowly elliptic leaves, small, round fruits, and tetrahedral seeds.

Specimens examined:

Bolivia, Dpto. Potosí: Nor Chichas, Carretera Potosi-Orkhola-Tumusla, $5 \mathrm{~km} \mathrm{~N}$ of Orkhola, dry west facing slope with Cactus and Acacia, $20.39654^{\circ} \mathrm{S} 65.56432^{\circ} \mathrm{W}, 3113 \mathrm{~m}, 18 / \mathrm{II} / 04$, shrub, $1.5 \mathrm{~m}$ tall, imm. fruit green, S. D. Smith, S. Leiva G., S. J. Hall 383 (HAO, F, NY, LPB, WIS); Bolivia, Dpto. Potosí: Nor Chichas, Carretera Potosi-Orkhola-Tumusla, $5 \mathrm{~km} \mathrm{~N}$ of Orkhola, dry west facing slope with Cactus and Acacia, $20.39654^{\circ} \mathrm{S} 65.56432^{\circ} \mathrm{W}, 3113 \mathrm{~m}, 18 / \mathrm{II} / 04$, shrub, $1.5 \mathrm{~m}$ tall, senescing flowers yellow, imm. fruit and calyx green, S. D. Smith, S. Leiva G., S. J. Hall 384 (HAO, F, MO, LPB, WIS); Bolivia, Dpto. Potosí: Nor Chichas, Carretera Potosi-Orkhola-Tumusla, $5 \mathrm{~km} \mathrm{~N}$ of Orkhola, dry west facing slope with Cactus and Acacia, $20.39638^{\circ} \mathrm{S} 65.56287^{\circ} \mathrm{W}, 3099 \mathrm{~m}, 18 / \mathrm{II} / 04$, shrub, $1.5 \mathrm{~m}$ tall, senescing flowers yellow, imm. fruit and calyx green, S. D. Smith, S. Leiva G., S. J. Hall 385 (HAO, F, MO, NY, LPB, WIS); Bolivia, Dpto. Potosí: Nor Chichas, Carretera Potosi-Orkhola-Tumusla, a few km S of Orkhola, $20.43705^{\circ} \mathrm{S} 65.5815^{\circ} \mathrm{W}, 2991 \mathrm{~m}, 18 / \mathrm{II} / 04$, shrub, $2 \mathrm{~m}$ tall, flowers yellow, greenish towards base, calyx green, nectary red, S. D. Smith, S. Leiva G., S. J. Hall 386 (HAO, F, MO, NY, LPB, WIS); Bolivia, Dpto. Potosí: Nor Chichas, a ca. $110 \mathrm{~km}$ al SO de Potosí, rumbo a Tumusla, $20^{\circ} 25^{\prime} 06,2^{\prime \prime} / 20^{\circ} 25^{\prime} 04,3^{\prime \prime} \mathrm{S}, 65^{\circ} 34^{\prime} 17,2^{\prime \prime} / 65^{\circ} 34^{\prime} 16,6 " \mathrm{~W}, 26-X I-2012$, arbusto de 1,5-2 m alt., con ramas espinescentes, cáliz verde, corola amarilla, androceo y gineceo equilongos, filamentos estaminales y ovario blanquecinos, nectario rojo, estilo blanquecino, estigma diminuto, al costado de la ruta, Barboza \& Carrizo García 3643 (CORD).

Distribution: At present, there exist only ten collections of this Trompettia cardenasiana, all deriving from a small region in southern Bolivia in the department of Potosí, province of Nor Chichas, north of Santiago de Cotagaita. This record suggests that the species is rare (albeit still extant) in its native environment. However, we caution that Bolivia remains underexplored botanically such that future fieldwork in the area and surrounding countries may yield discovery of new, additional populations. 
581 Notes: To reflect a more complete understanding of this species in light of additional material 582 collected since the holotype, we have provided a fuller, revised species description that expands 583 upon the original description presented by Hunziker (1977).

601

602

603

\section{Taxonomic Treatment}

Accepted taxa:

Datureae G. Don., Gen. Hist.: 4, 472. 1838: Brugmansia Pers., Datura L., Trompettia J. Dupin

Brugmansia Pers. (only non-hybrid Brugmansia sensu Lockwood, 1973): Brugmansia arborea (L.) Lagerh., B. aurea Lagerh., B. sanguinea (Ruiz \& Pav.) D. Don, B. suaveolens (Humb. \& Bonpl. ex Willd.) Sweet, B. versicolor Lagerh.

Datura L.: D. arenicola Gentry ex Bye \& Luna-Cavazos, D. ceratocaula Ortega, D. discolor Bernh., D. inoxia Mill., D. kymatocarpa A.S. Barclay, D. lanosa Barclay ex Bye, D. leichhardtii spp. pruinosa (Greenm.) A.S. Barclay ex K. Hammer, D. metel L., D. quercifolia Kunth, D. reburra A.S. Barclay, D. stramonium L., D. wrightii Regel

Trompettia J.Dupin: T. cardenasiana (Hunz.) J.Dupin 


\section{Taxonomic Key of Worldwide Diversity in Datureae}

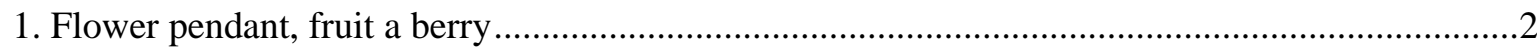

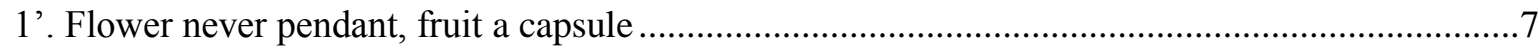

2. Flower 2.5 to $3.5 \mathrm{~cm}$ long, corolla always yellow

T. cardenasiana

$2^{\prime}$. Flower $>3.5 \mathrm{~cm}$, corolla rarely yellow.....

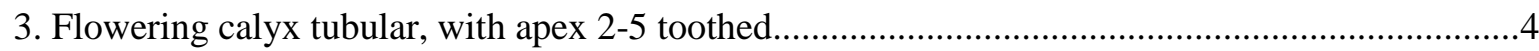

3'. Flowering calyx spathe-like, clearly splitting along one side and tapering to a long point, apex not toothed.

4. Flower more than $25 \mathrm{~cm}$ long, corolla tube constricted beyond calyx, fruit oblong ..... B. versicolor 4'. Flower 15 to $20 \mathrm{~cm}$, corolla tube not constricted beyond calyx, fruit ovoid

B. arborea

$$
\text { 5. Corolla tubular, base yellow and apex red }
$$

B. sanguinea

5'. Corolla not tubular, base not yellow

6. Flowering calyx glabrous, corolla tube constricted beyond calyx apex (Fig. 6 a), anthers connivent to free, B. suaveolens

6'. Flowering calyx slightly pubescent, corolla tube not constricted beyond calyx apex, anthers free

7. Leaf abaxial surface of white coloration, different from the green coloration of the adaxial surface, fruit surface spiny

7'. Leaves slender, leaf abaxial surface green, similar color to adaxial surface, fruit surface not spiny, surface smooth D. ceratocaula

8. Leaves usually not slender, Leaves sinuately dentate to pinnately lobed, fruit erect, seed without elaiosome. 
12 '. Leaves pubescent, fruit spines not reduced, sharp to the touch, corolla with single vertical and not purple on the outside 13

13. Corolla outer surface glabrous D. inoxia 13'. Corolla outer surface pubescent 14 14. Leaf surface densely covered with short trichomes giving it a gray aspect; leaf has peanut butter smell when rubbed D. wrightii 14'. Leaf surface covered with fine, long trichomes giving it a white and lanate aspect; leaf has no peanut butter smell

D. lanosa D. kymatocarpa $15^{\prime}$. Seed coat not verrucose 16

16. Circumscissile fruiting calyx deflexed D. leichhardtii ssp. pruinosa 16'. Circumscissile fruiting calyx reflexed 17 17. Corolla longer than $8 \mathrm{~cm}$, with purple throat D. discolor 17'. Corolla no longer than $4 \mathrm{~cm}$, without purple throat

D. arenicola

\section{Acknowledgments}

The authors thank J. Mark Porter, Susanne Renner, Lynn Bohs, and Richard Olmstead for contributing with DNA samples to this study. We also thank Gerard van der Weerden, curator of the Solanaceae Collection at the Radboud University's Experimental Garden (Netherlands), for his help with Datureae seed samples, and Sean Lahmeyer, plant conservation specialist at The Huntington Botanical Gardens (CA), for his help with Brugmansia samples. The authors also appreciate the valuable feedback on this work provided by Rocío Deanna, Christy McCain, Pam Diggle, Dan Doak, and, especially, Erin Tripp. Finally, we thank two anonymous reviewers, and editors at Taxon for their constructive comments on this manuscript.

This work was supported by the National Science Foundation grant to SDS (NSF-DEB 1413855), and JD received support from the Department of Ecology and Evolutionary Biology and Museum of Natural History at CU Boulder, the School of Biological Sciences at the University of Nebraska Lincoln, the American Society of Plant Taxonomists, the Torrey Botanical Society, and Society of Systematic Biologists.

\section{Author Contributions}

J.D. and S.D.S designed the research; J.D. performed the research; J.D. collected and analyzed the data, J.D. and S.D.S interpreted the results; J.D. led the writing with fundamental contributions and revisions from S.D.S. Both co-authors read and approved the article.

\section{Literature Cited}


Andreasen, K., Baldwin, B. G., \& Bremer, B. 1999. Phylogenetic utility of the nuclear rDNA ITS region in subfamily Ixoroideae (Rubiaceae): Comparisons with cpDNA rbcL sequence data. Plant Syst. Evol., 217: 119-135. https://doi.org/10.1007/bf00984925

Antonelli, A., Nylander, J. A. A., Persson, C., \& Sanmartin, I. 2009. Tracing the impact of the Andean uplift on Neotropical plant evolution. Proc. Natl. Acad. Sci., 106: 9749-9754. https://doi.org/10.1073/pnas.0811421106

Barclay, A. S. 1959. Studies in the genus Datura (Solanaceae). Dissertation, Harvard University, Cambridge, Massachusetts, USA.

Baum, D. A., Sytsma, K. J., \& Hoch, P. C. 1994. A phylogenetic analysis of Epilobium (Onagraceae) based on nuclear ribosomal DNA sequences. Syst. Bot., 19: 363-363. https://doi.org/10.2307/2419763

Bernhardi, J. J. 1833. Über die arten der gattung Datura. Neues J. Pharm. Aerzte Apoth. Chem., 26: $118-158$.

Blandin, P., \& Purser, B. 2013. Evolution and diversification of Neotropical butterflies: Insights from the biogeography and phylogeny of the genus Morpho Fabricius, 1807 (Nymphalidae: Morphinae), with a review of the geodynamics of South America. Trop. Lepidoptera Res., 23: $62-85$.

Bouckaert, R., Heled, J., Kühnert, D., Vaughan, T., Wu, C.-H., Xie, D., Suchard, M. A., Rambaut, A., \& Drummond, A. J. 2014. BEAST 2: A Software Platform for Bayesian Evolutionary Analysis. PLoS Comput. Biol., 10. https://doi.org/10.1371/journal.pcbi.1003537

Bronstein, J. L., Huxman, T., Horvath, B., Farabee, M., \& Davidowitz, G. 2009. Reproductive biology of Datura wrightii: the benefits of a herbivorous pollinator. Ann. Bot., 103: 14351443. https://doi.org/10.1093/aob/mcp053 
Bye, R., \& Sosa, V. 2013. Molecular phylogeny of the jimsonweed genus Datura (Solanaceae). Syst. Bot., 38: 818-829. https://doi.org/10.1600/036364413x670278

Carson, G. L. 1945. The crossability of Datura quercifolia with seven species of the genus. Dissertation, Smith College, Northampton, Massachusetts, USA.

Cruz-Mazo, G., Buide, M. L., Samuel, R., \& Narbona, E. 2009. Molecular phylogeny of Scorzoneroides (Asteraceae): Evolution of heterocarpy and annual habit in unpredictable environments. Mol. Phylogenet. Evol., 53: 835-847. https://doi.org/10.1016/j.ympev.2009.08.001

D’Arcy, W. G. 1986. Solanaceae, Biology and systematics. New York: Columbia University Press.

D’Arcy, W. G. 1991. The Solanaceae since 1976, with a review of its biogeography. Pp. 75-137 in: Hawkes, J.G., Lester, R.N., Nee, M., Estrada, N. (eds.) Solanaceae III Taxonomy, Chemistry, Evolution London: Royal Botanic Gardens, Kew.

\section{De-Silva, D. L., Mota, L. L., Chazot, N., Mallarino, R., Silva-Brandão, K. L., Piñerez, L. M.} G., Freitas, A. V. L., Lamas, G., Joron, M., Mallet, J., \& others. 2017. North Andean origin and diversification of the largest ithomiine butterfly genus. Sci. Rep., 7: 45966. https://doi.org/10.1038/srep45966

Doyle, J. J. 1987. A rapid DNA isolation procedure for small quantities of fresh leaf tissue. Phytochem Bull, 19: 11-15.

Drummond, A. J., Ho, S. Y. W., Phillips, M. J., \& Rambaut, A. 2006. Relaxed phylogenetics and dating with confidence. PLoS Biol., 4: e0040088. https://doi.org/10.1371/journal.pbio.0040088

Drummond, A. J., Suchard, M. A., Xie, D., \& Rambaut, A. 2012. Bayesian phylogenetics with BEAUti and the BEAST 1.7. Mol. Biol. Evol., 29: 1969-1973. https://doi.org/10.1093/molbev/mss075 
Edgar, R. C. 2004. MUSCLE: multiple sequence alignment with high accuracy and high throughput. Nucleic Acids Res., 32: 1792-1797. https://doi.org/10.1093/nar/gkh340

Ege, H., Sobel, E. R., Scheuber, E., \& Jacobshagen, V. 2007. Exhumation history of the southern Altiplano plateau (southern Bolivia) constrained by apatite fission track thermochronology. Tectonics, 26: TC1004. https://doi.org/10.1029/2005tc001869

\section{Evans, M. E. K., Hearn, D. J., Hahn, W. J., Spangle, J. M., Venable, D. L., \& Pellmyr, O.} 2005. Climate and life-history evolution in evening primroses (Oenothera, Onagraceae): a phylogenetic comparative analysis. Evolution, 59: 1914-1927. https://doi.org/10.1554/04708.1

Friedman, J., \& Rubin, M. J. 2015. All in good time: Understanding annual and perennial strategies in plants. Am. J. Bot., 102: 497-499. https://doi.org/10.3732/ajb.1500062

Graham, A. 2009. The Andes: a geological overview from a biological perspective. Ann. Mo. Bot. Gard., 96: 371-385. https://doi.org/10.3417/2007146

Hay, A., Gottschalk, M., \& Holguín, A. 2012. Huanduj: Brugmansia. Richmond: Royal Botanic Gardens, Kew.

He, C., Münster, T., \& Saedler, H. 2004. On the origin of floral morphological novelties. FEBS Lett., 567: 147-151. https://doi.org/10.1016/j.febslet.2004.02.090

Hillis, D. M., \& Huelsenbeck, J. P. 1992. Signal, noise, and reliability in molecular phylogenetic analyses. J. Hered., 83: 189-195. https://doi.org/10.1093/oxfordjournals.jhered.a111190

Hu, J.-Y., \& Saedler, H. 2007. Evolution of the inflated calyx syndrome in Solanaceae. Mol. Biol. Evol., 24: 2443-2453. https://doi.org/10.1093/molbev/msm177

Huelsenbeck, J. P., Nielsen, R., \& Bollback, J. P. 2003. Stochastic mapping of morphological characters. Syst. Biol., 52: 131-158. https://doi.org/10.1080/10635150309342

Hunziker, A. T. 1977. Estudios sobre Solanaceae VIII. Part IV. Sobre dos nuevas secciones de Iochroma y dos novedades a nivel específico. Kurtziana, 10: 21-25. 
Hunziker, A. T. 2001. Genera Solanacearum: the genera of Solanaceae illustrated, arranged according to a new system. Ruggell: A.R.G. Gantner Verlag K.G.

Joshi, P. C. 1949. A comparative study of two intergeneric hybrids, Datura inoxia Mill. X. Brugmansia suaveolens Humb. \& Bonpl. and Datura inoxia Mill. X Brugmansia rosei Saff., and their parents: And self-sterility in three species of Brugmansia Pers. Dissertation, Smith College, Northampton, Massachusetts, USA.

Knudsen, J. T., \& Tollsten, L. 1993. Trends in floral scent chemistry in pollination syndromes: floral scent composition in moth-pollinated taxa. Bot. J. Linn. Soc., 113: 263-284. https://doi.org/10.1111/j.1095-8339.1993.tb00340.x

Leiva Gonzalez, S. 2010. Nicandra yacheriana (Solanaceae) una nueva especie del Sur del Perú. Arnaldoa, 17: 25-31.

Leiva Gonzalez, S., \& Pereyra Villanueva, E. 2007. Nicandra john-tyleriana (Solanaceae): una nueva especie del norte del Perú. Arnaldoa, 14: 45-52.

Lengyel, S., Gove, A. D., Latimer, A. M., Majer, J. D., \& Dunn, R. R. 2009. Ants sow the seeds of global diversification in flowering plants. PLOS ONE, 4: 0005480. https://doi.org/10.1371/journal.pone.0005480

Lengyel, S., Gove, A. D., Latimer, A. M., Majer, J. D., \& Dunn, R. R. 2010. Convergent evolution of seed dispersal by ants, and phylogeny and biogeography in flowering plants: A global survey. Perspect. Plant Ecol. Evol. Syst., 12: 43-55. https://doi.org/10.1016/j.ppees.2009.08.001

Levin, R. A., \& Miller, J. S. 2005. Relationships within tribe Lycieae (Solanaceae): paraphyly of Lycium and multiple origins of gender dimorphism. Am. J. Bot., 92: 2044-2053. https://doi.org/10.3732/ajb.92.12.2044

Lockwood, T. E. 1973. A taxonomic revision of Brugmansia (Solanaceae). Dissertation, Harvard University, Cambridge, Massachusetts, USA. 
Luna-Cavazos, M., Bye, R., \& Jiao, M. 2008. The origin of Datura metel (Solanaceae): genetic and phylogenetic evidence. Genet. Resour. Crop Evol., 56: 263-275. https://doi.org/10.1007/s10722-008-9363-5

Maddison, W. P., \& Maddison, D. R. 2017. Mesquite: a modular system for evolutionary analysis, Version 3.2. http://mesquiteproject.org

Magallón, S., Gómez-Acevedo, S., Sánchez-Reyes, L. L., \& Hernández-Hernández, T. 2015. A metacalibrated time-tree documents the early rise of flowering plant phylogenetic diversity. New Phytol., 207: 437-453. https://doi.org/10.1111/nph.13264

Marussich, W. A. 2006. Testing myrmecochory from the ant's perspective: The effects of Datura wrightii and D. discolor on queen survival and brood production in Pogonomyrmex californicus. Insectes Sociaux, 53: 403-411. https://doi.org/10.1007/s00040-005-0888-3

Mason-Gamer, R. J., \& Kellogg, E. A. 1996. Testing for phylogenetic conflict among molecular data sets in the Tribe Triticeae (Gramineae). Syst. Biol., 45: 524-545. https://doi.org/10.1093/sysbio/45.4.524

McNeill, J., Barrie, F. R., Buck, W. R., Demoulin, V., Greuter, W., Hawksworth, D. L., Herendeen, P. S., Knapp, S., Marhold, K., Prado, J., \& others. 2012. International Code of Nomenclature for algae, fungi and plants. Regnum Veg., 154.

Millan, M., \& Crepet, W. 2014. The fossil record of the Solanaceae revisited and revised-The fossil record of Rhamnaceae enhanced. Bot. Rev., 80: 73-106. https://doi.org/10.1007/s12229-014-9134-2

Ng, J., \& Smith, S. D. 2015. Widespread flower color convergence in Solanaceae via alternate biochemical pathways. New Phytol., 209: 407-417. https://doi.org/10.1111/nph.13576

Nielsen, R. 2002. Mapping mutations on phylogenies. Syst. Biol., 51: 729-739. https://doi.org/10.1080/10635150290102393 
O’Dowd, D. J., \& Hay, M. E. 1980. Mutualism between harvester ants and a desert ephemeral: seed escape from rodents. Ecology, 61: 531-540. https://doi.org/10.2307/1937419

Ogilvie, H. A., \& Drummond, A. J. 2016. StarBEAST2 brings faster species tree inference and accurate estimates of substitution rates. bioRxiv, 070169-070169.

\section{Olmstead, R. G., Bohs, L., Migid, H. A., Santiago-Valentin, E., Garcia, V. F., \& Collier, S. M.} 2008. A molecular phylogeny of the Solanaceae. Taxon, 57: 1159-1181.

Olmstead, R. G., \& Palmer, J. D. 1992. A chloroplast DNA phylogeny of the Solanaceae: subfamilial relationships and character evolution. Ann. Mo. Bot. Gard., 79: 346-346. https://doi.org/10.2307/2399773

Olmstead, R. G., \& Sweere, J. A. 1994. Combining data in phylogenetic systematics: An empirical approach using three molecular data sets in the Solanaceae. Syst. Biol., 43: 467481. https://doi.org/10.1093/sysbio/43.4.467

Olmstead, R. G., Sweere, J. A., Spangler, R. E., Bohs, L., \& Palmer, J. D. 1999. Phylogeny and provisional classification of the Solanaceae based on chloroplast DNA. Solanaceae IV, 1: $1-137$.

Paradis, E., Claude, J., \& Strimmer, K. 2004. APE: analyses of phylogenetics and evolution in R language. Bioinformatics, 20: 289-290. https://doi.org/10.1093/bioinformatics/btg412

Pennington, R. T., Lavin, M., Sarkinen, T., Lewis, G. P., Klitgaard, B. B., \& Hughes, C. E. 2010. Contrasting plant diversification histories within the Andean biodiversity hotspot. Proc. Natl. Acad. Sci., 107: 13783-13787. https://doi.org/10.1073/pnas.1001317107

Peralta, I. E., \& Spooner, D. M. 2001. Granule-bound starch synthase (GBSSI) gene phylogeny of wild tomatoes (Solanum L. Section Lycopersicon [Mill.] Wettst. Subsection Lycopersicon). Am. J. Bot., 88: 1888-1902. https://doi.org/10.2307/3558365 
Persoon, C. H. 1805. Synopsis plantarum, seu Enchiridium botanicum, complectens enumerationem systematicam specierum hucusque cognitarum. Paris: C.F. Cramerum. https://doi.org/10.5962/bhl.title.638

Raguso, R. A., Henzel, C., Buchmann, S. L., \& Nabhan, G. P. 2003. Trumpet flowers of the Sonoran Desert: floral biology of Peniocereus cacti and sacred Datura. Int. J. Plant Sci., 164: 877-892. https://doi.org/10.1086/378539

Rambaut, A., Suchard, M. A., Xie, D., \& Drummond, A. J. 2014. Tracer v1.6. Program distributed by the authors. http://tree.bio.ed.ac.uk/software/tracer

Revell, L. J. 2011. phytools: an R package for phylogenetic comparative biology (and other things). Methods Ecol. Evol., 3: 217-223. https://doi.org/10.1111/j.2041-210x.2011.00169.x

Rice, A., Glick, L., Abadi, S., Einhorn, M., Kopelman, N. M., Salman-Minkov, A., Mayzel, J., Chay, O. \& Mayrose, I. 2015. The Chromosome Counts Database (CCDB) - a community resource of plant chromosome numbers. New Phytol., 206: 19-26. https://doi.org/10.1111/nph.13191

Safford, W. E. 1921. Synopsis of the genus Datura. J. Wash. Acad. Sci., 11: 173-189.

Särkinen, T., Bohs, L., Olmstead, R. G., \& Knapp, S. 2013. A phylogenetic framework for evolutionary study of the nightshades (Solanaceae): a dated 1000-tip tree. BMC Evol. Biol., 13: 214-214. https://doi.org/10.1186/1471-2148-13-214

Schultes, R. E., \& Hofmann, A. 1973. The botany and chemistry of hallucinogens. Springfield: Charles C Thomas Publisher.

Schultz, E. A., \& Haughn, G. W. 1991. LEAFY, a homeotic gene that regulates inflorescence development in Arabidopsis. Plant Cell, 3: 771-771. https://doi.org/10.2307/3869271

Sébrier, M., Lavenu, A., Fornari, M., \& Soulas, J. P. 1988. Tectonics and uplift in Central Andes (Peru, Bolivia and northern Chile) from Eocene to present. Géodynamique, 3: 85-106. 
844 Smith, S. D., \& Baum, D. A. 2006. Phylogenetics of the florally diverse Andean clade

845

846

847 848

849

850

851

852

853

854

855

856

857

858

859

860

861

862

863

864

865

866

867

868
Iochrominae (Solanaceae). Am. J. Bot., 93: 1140-1153.

https://doi.org/10.3732/ajb.93.8.1140

Solís-Lemus, C., \& Ané, C. 2016. Inferring phylogenetic networks with maximum pseudolikelihood under incomplete lineage sorting. PLoS Genetics, 12: e1005896. https://doi.org/10.1371/journal.pgen.1005896

Soltis, D. E., \& Kuzoff, R. K. 1995. Discordance between nuclear and chloroplast phylogenies in the Heuchera group (Saxifragaceae). Evolution, 49: 727-727. https://doi.org/10.2307/2410326

Swofford, D. L. 2003. PAUP* Phylogenetic analysis using parsimony (* and other methods), Version 4. Sinauer Associates Sunderland, MA.

Team, R. C. 2015. R: a language and environment for statistical computing. https://www.rproject.org/

Tu, T., Dillon, M. O., Sun, H., \& Wen, J. 2008. Phylogeny of Nolana (Solanaceae) of the Atacama and Peruvian deserts inferred from sequences of four plastid markers and the nuclear LEAFY second intron. Mol. Phylogenet. Evol., 49: 561-573. https://doi.org/10.1016/j.ympev.2008.07.018

Velichkevich, F., \& Zastawniak, E. 2003. The Pliocene flora of Kholmech, south-eastern Belarus and its correlation with other Pliocene floras of Europe. Acta Palaeobot, 43: 137-259.

Weiss, M. R. 1995. Floral color change: A widespread functional convergence. Am. J. Bot., 82: 167-167. https://doi.org/10.2307/2445525

Wendel, J. F., \& Doyle, J. J. 1998. Phylogenetic Incongruence: window into genome history and molecular evolution. Pp. 265--296 in: Soltis, D.E., Soltis, P.S., Doyle, J.J. (eds.) Molecular Systematics of Plants II. New York: Springer. https://doi.org/10.1007/978-1-4615-5419$6 \_10$ 
869 Wettstein, R. 1895. Die Natürlichen Pflanzenfamilien 4(3b).

870 White, T. J., Bruns, T., Lee, S. J. W. T., Taylor, J. W. 1990. Amplification and direct sequencing 871 of fungal ribosomal RNA genes for phylogenetics. Pp. 315--322 in: Innis, M.A., Gelfand,

872 D.H., Sninsky, J.J., White, T.J. (eds.) PCR protocols, a guide to methods and applications.

873 London: Academic Press.

874 Whitson, M., Manos, P. S., \& Plunkett, G. M. 2005. Untangling Physalis (Solanaceae) from the 875 physaloids: a two-gene phylogeny of the Physalinae. Syst. Bot., 30: 216-230.

876 https://doi.org/10.1600/0363644053661841

877 Wilf, P., Carvalho, M. R., Gandolfo, M. A., \& Cúneo, N. R. 2017. Eocene lantern fruits from 878 Gondwanan Patagonia and the early origins of Solanaceae. Science, 355: 71-75.

879 https://doi.org/10.1126/science.aag2737

880 


\section{Author Contributions}

J.D. and S.D.S designed the research; J.D. performed the research; J.D. collected and analyzed the data, J.D. and S.D.S interpreted the results; J.D. led the writing with fundamental contributions and revisions from S.D.S. Both co-authors read and approved the article. 


\section{Figure Captions}

Figure 1. Flowers of different species of Datureae. A, Datura stramonium, B, D. wrightii, C, Trompettia cardenasiana (formerly Iochroma cardenasiana), D, Brugmansia sanguinea, E, $B$. suaveolens, and F, B. aurea. Scale bar (white) at the bottom left of each picture represents $1 \mathrm{~cm}$. Photos by J. Dupin.

Figure 2. 50\% majority rule consensus trees from parsimony bootstrap analysis on individual regions. Numbers on nodes indicate bootstrap support values. Outgroup species names were abbreviated to genus only (see Table 1 for full names).

Figure 3. Bayesian Maximum Clade Credibility phylogeny and divergence time estimation of Datureae and outgroups, as result from combined dataset analysis. Numbers on nodes represent posterior probabilities (pp); nodes with an asterisk have a pp of 1.0. Node bars represent the 95\% highest posterior density (HPD) of divergence times. Most recent common ancestor of Solanoideae pointed with arrow. Outgroup species names were abbreviated to genus only (see Table 1 for full names). Timescale represents main periods and epochs.

Figure 4. Ancestral state reconstruction of the following characters using stochastic mapping: flower orientation, fruit type, life history, seed margin, elaiosomes, fruit shape, and flower color. Below each reconstruction we indicate the mean number of transitions (changes) between the states given the indicated transition directionality.

Figure 5. Scientific illustration of Trompettia cardenasiana. A, Trompettia branch showing leaves, flower, fruit and flower bud. B, longitudinal section of flower. C, seed longitudinal section. D, gynoecium. E, fruit with fruiting calyx. F, fruit cross section. G, anther. Illustration by J. Dupin.

Figure 6. Diagrams illustrating corolla constriction and seed margins. A, corolla tube constricted beyond calyx. B, seed margin with triple-ridge. C, verrucose seed coat. Illustration by J. Dupin. 
ITS

$+5.85$

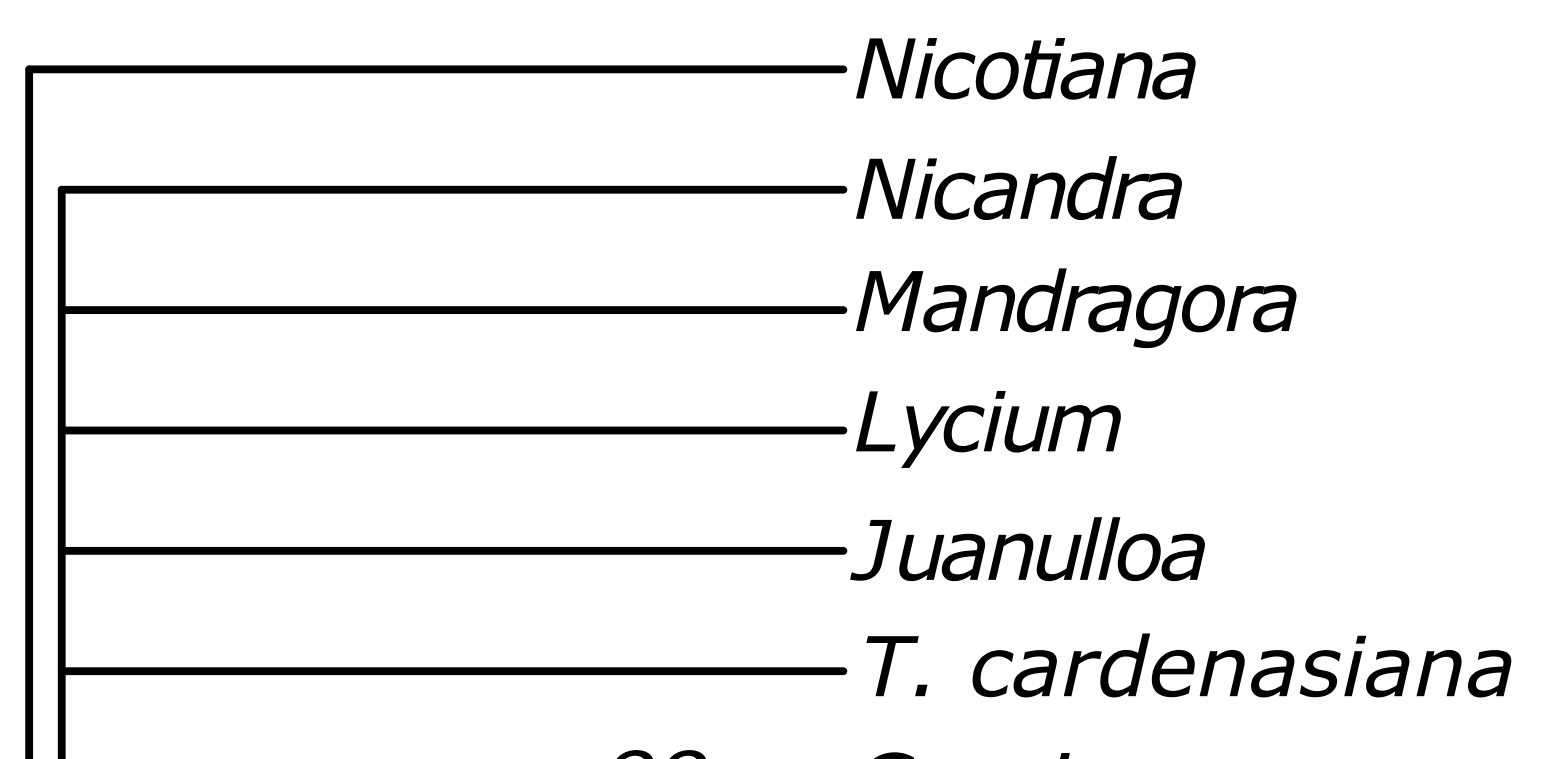

100 88 -Capsicum Solanum

77' Physalis

$71 \backslash{ }^{B}$. sanguinea

B. arborea

75 B. aurea

100 B. versicolor

51 B. suaveolens

D. ceratocaula

${ }^{92} y$ - D. stramonium

$99 \quad$ D. quercifolia

89 D. leichhardtii

${ }_{69} 71$ D. kymatocarpa

69 D. discolor

D. arenicola

D. reburra

D. metel

71 . inoxia

D. wrightii

$100^{\prime} D$. lanosa

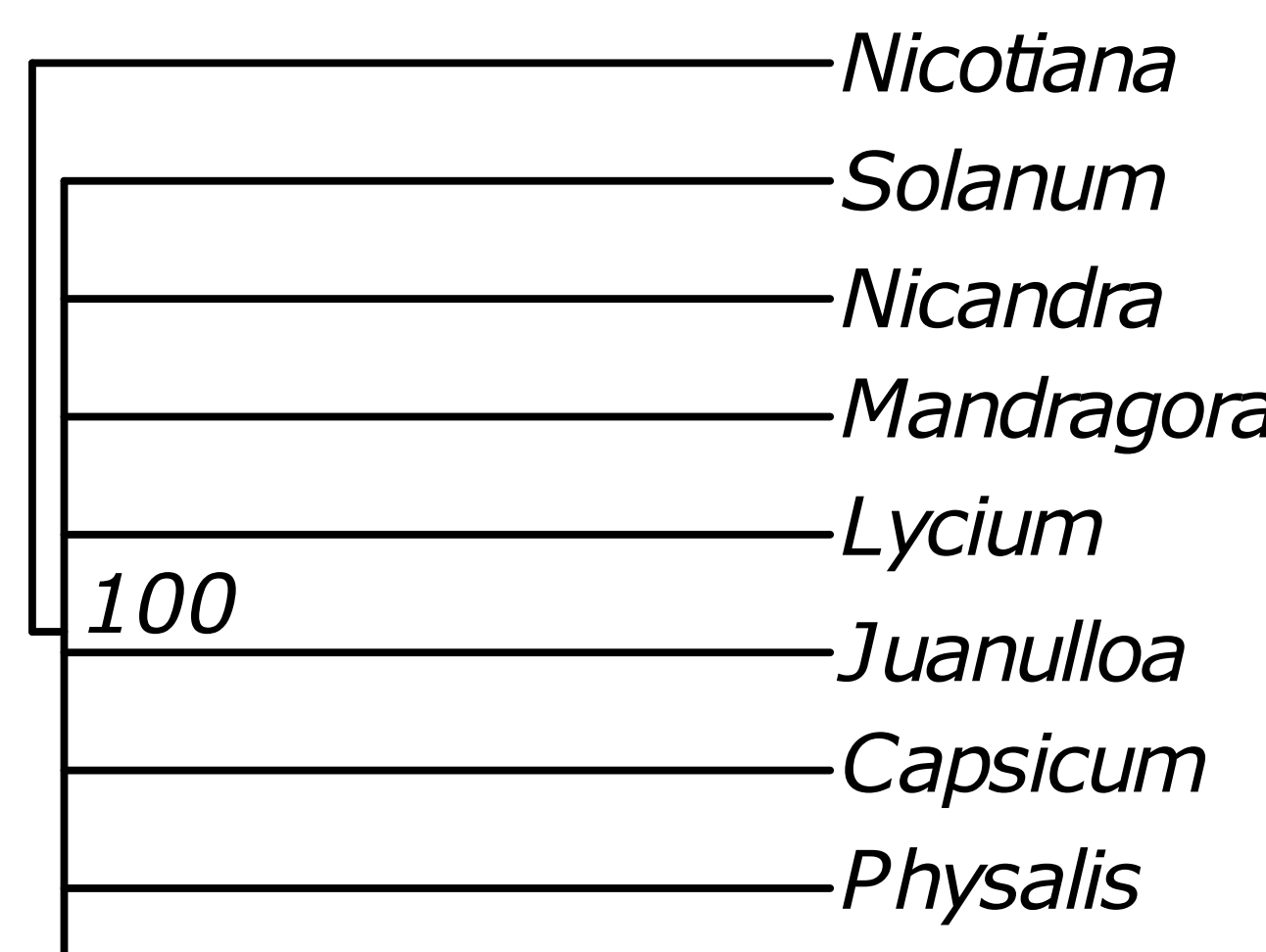

T. cardenasiana

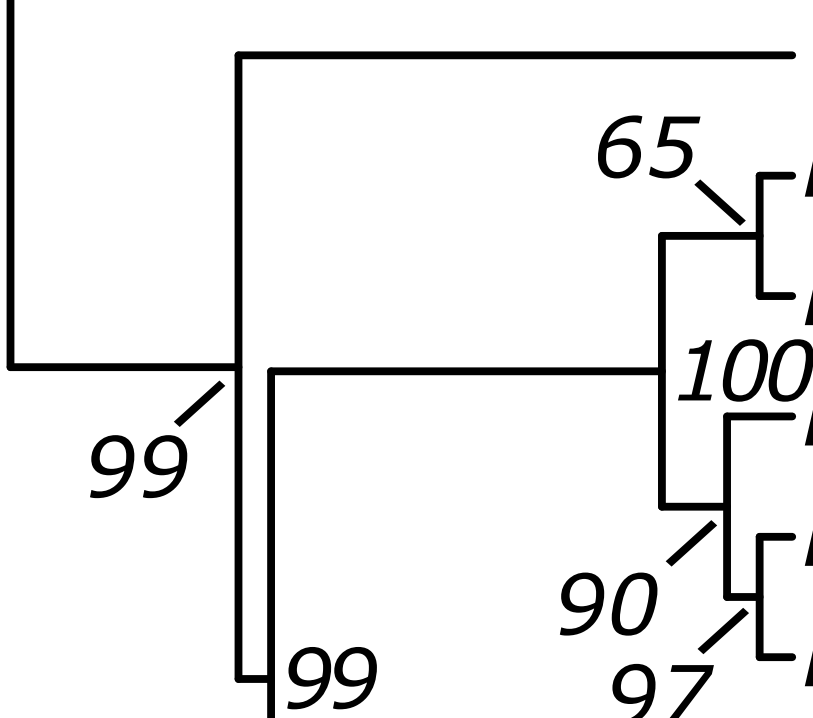

${ }^{B}$. sanguinea

B. arborea

100 . aurea

B. versicolor

$499 \quad 97^{\text {B. suaveolens }}$

D. leichhardtii

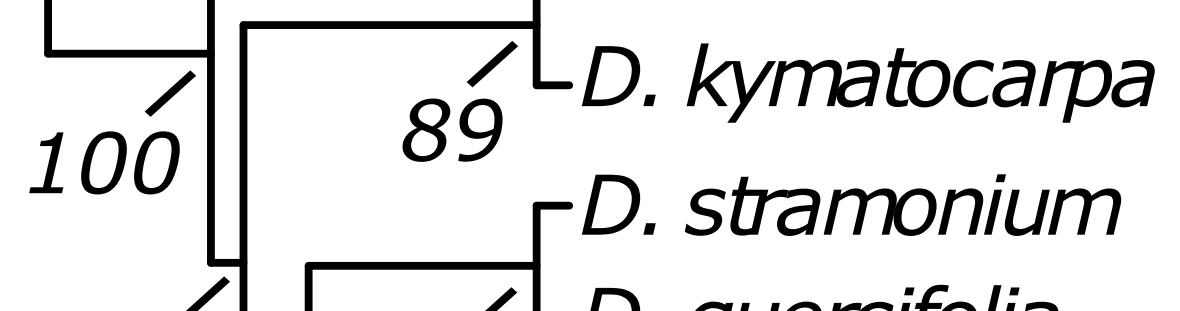

D. stramonium

$70 \quad 996$ D. quercifolia

77

D. reburra

D. metel

63 D. inoxia

D. wrighti

$97^{\prime} D$. lanosa

D. discolor

$63^{\prime}$ D. arenicola
Ify

T. cardenasiana

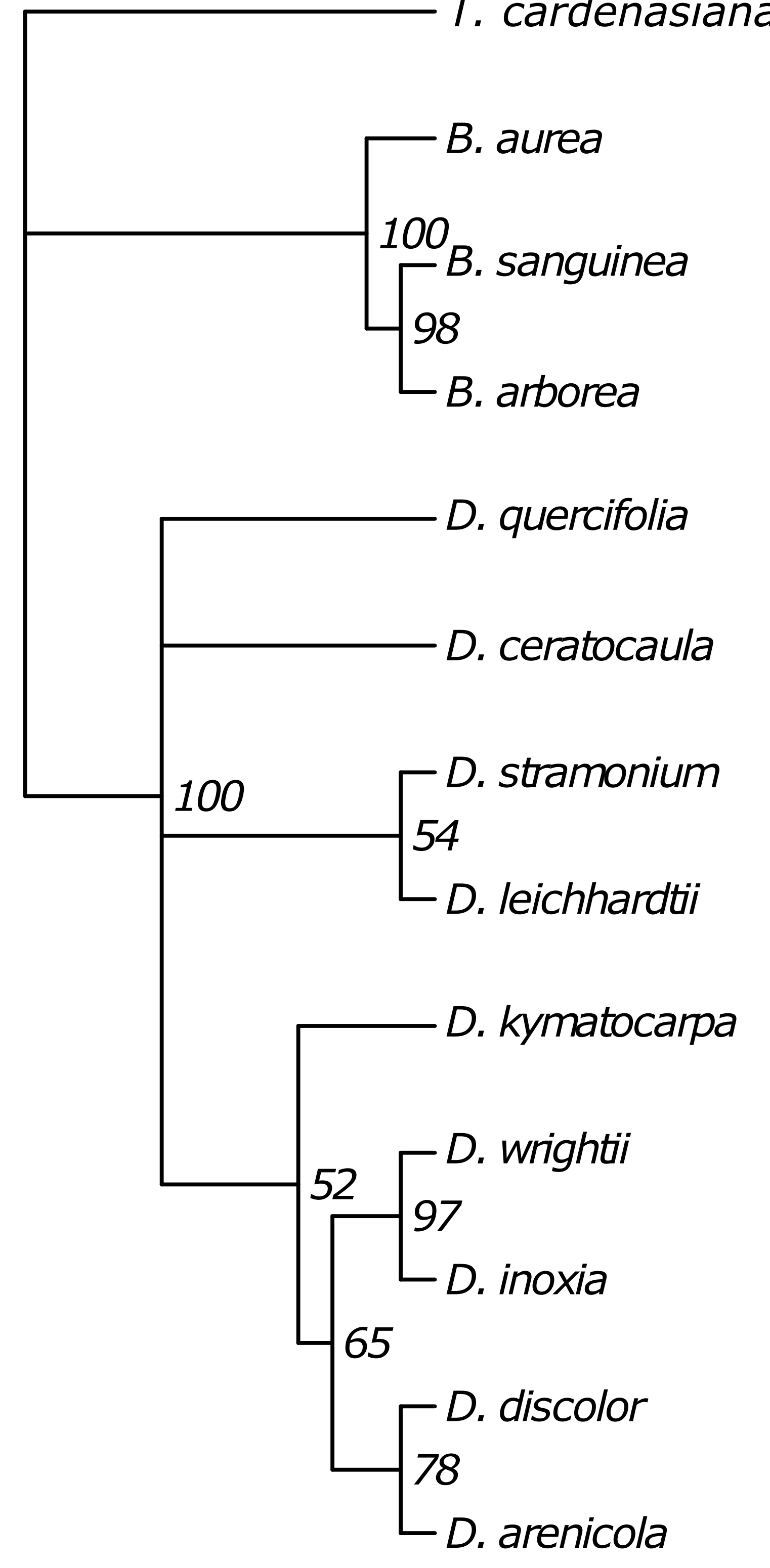


Click here to download Figure Figure3.pdf $\underline{\underline{\underline{ }}}$

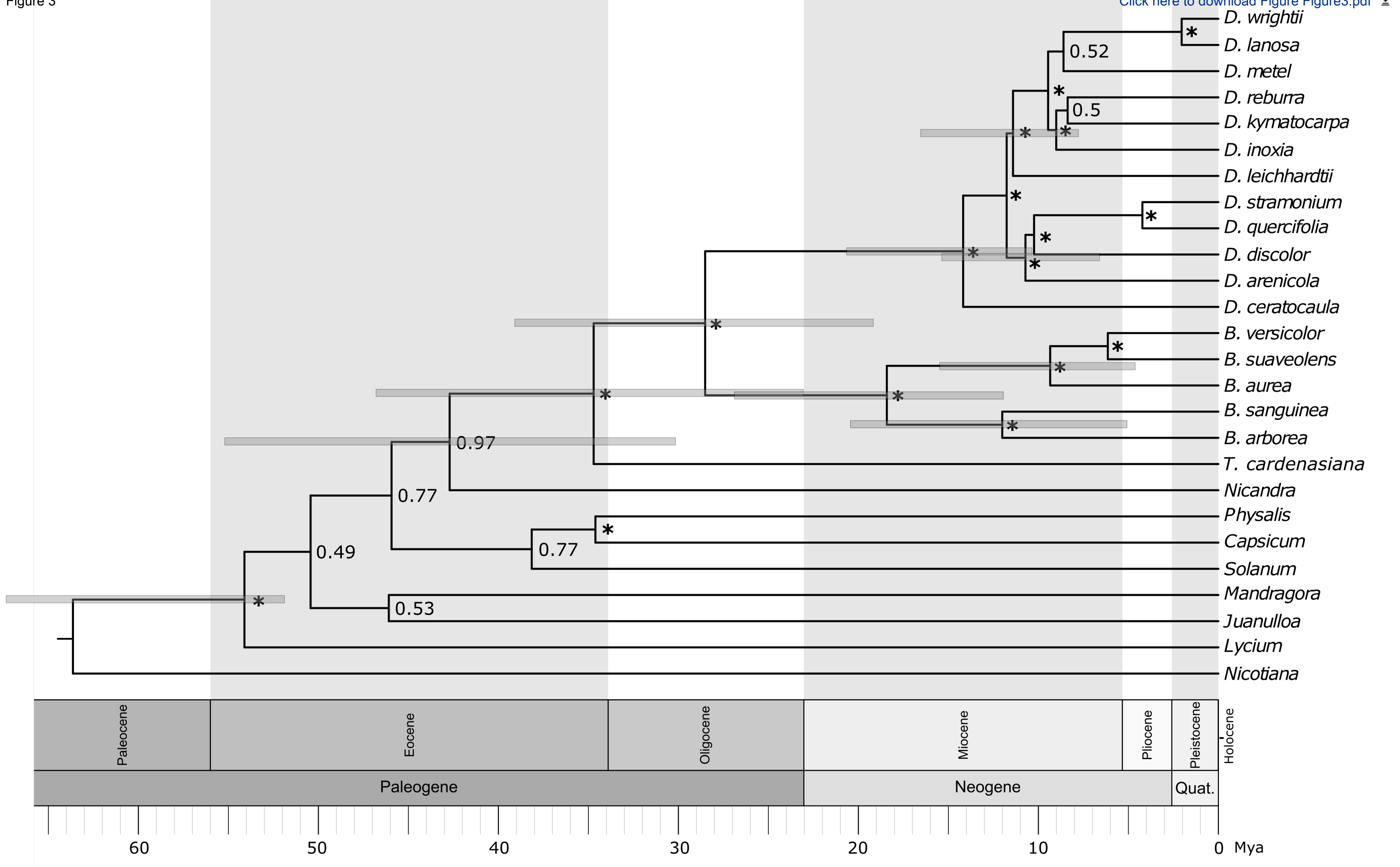


Flower orientation

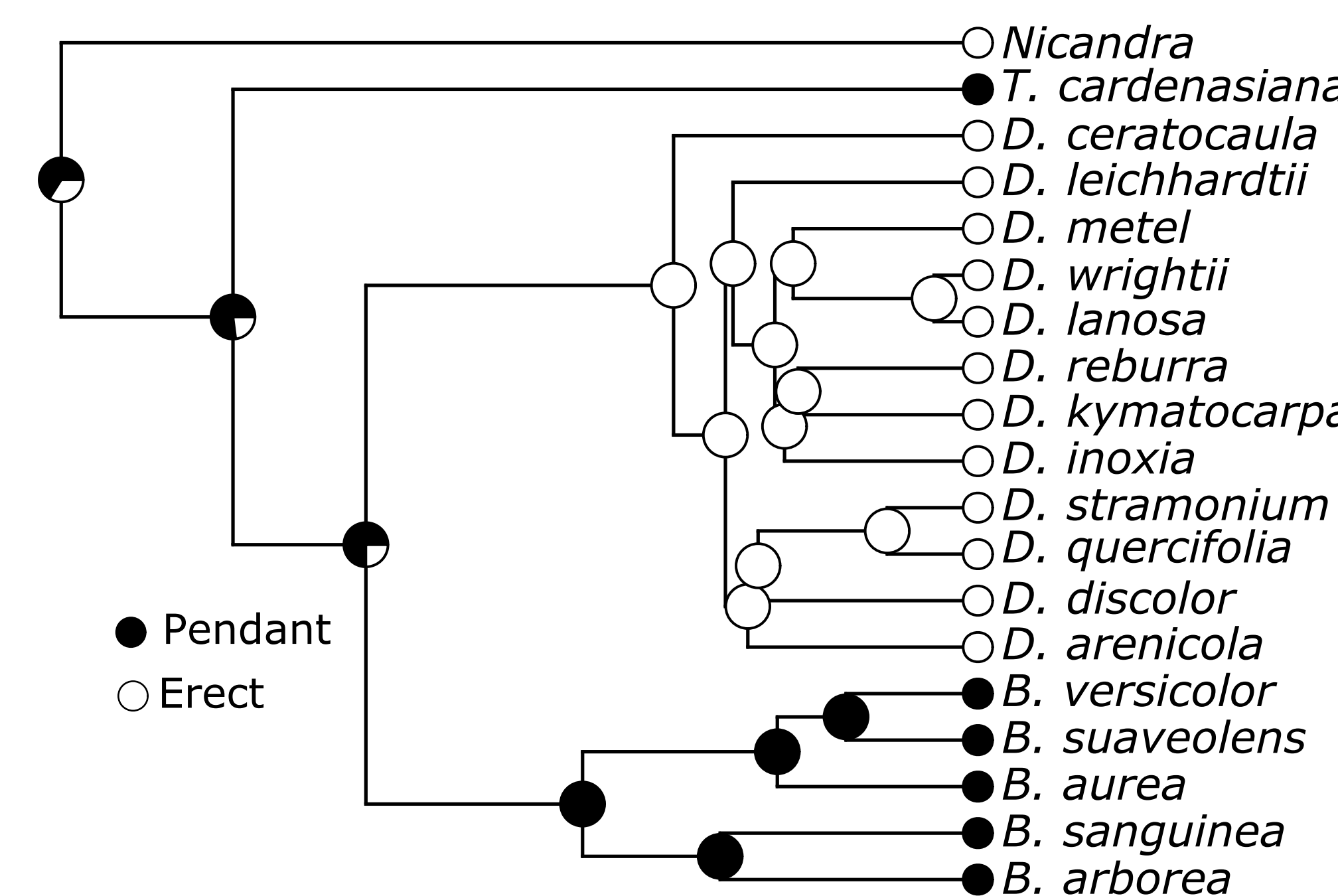

Mean $\mathrm{n}$ of transitions

(95\% C.I.)

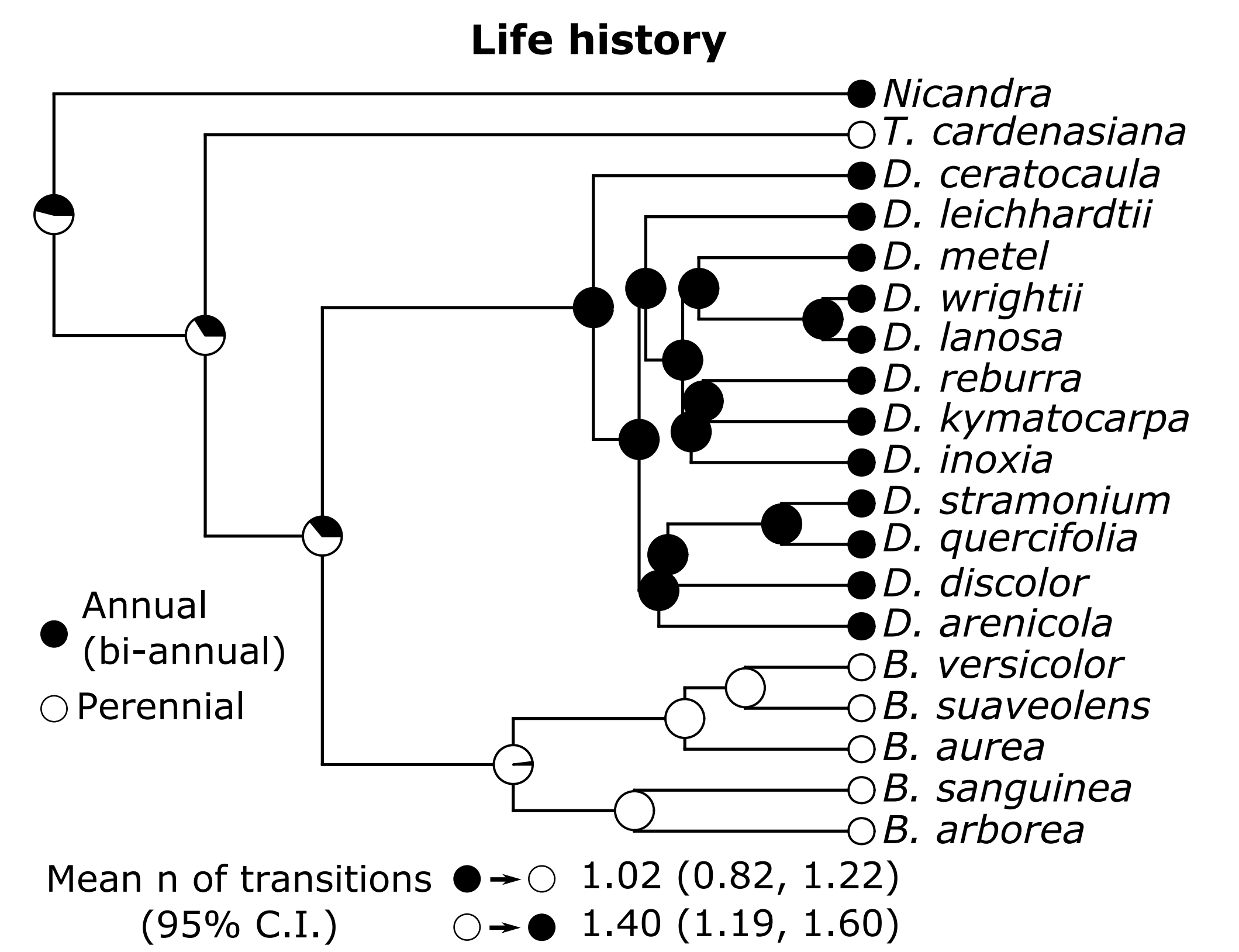

\section{Elaiosomes}

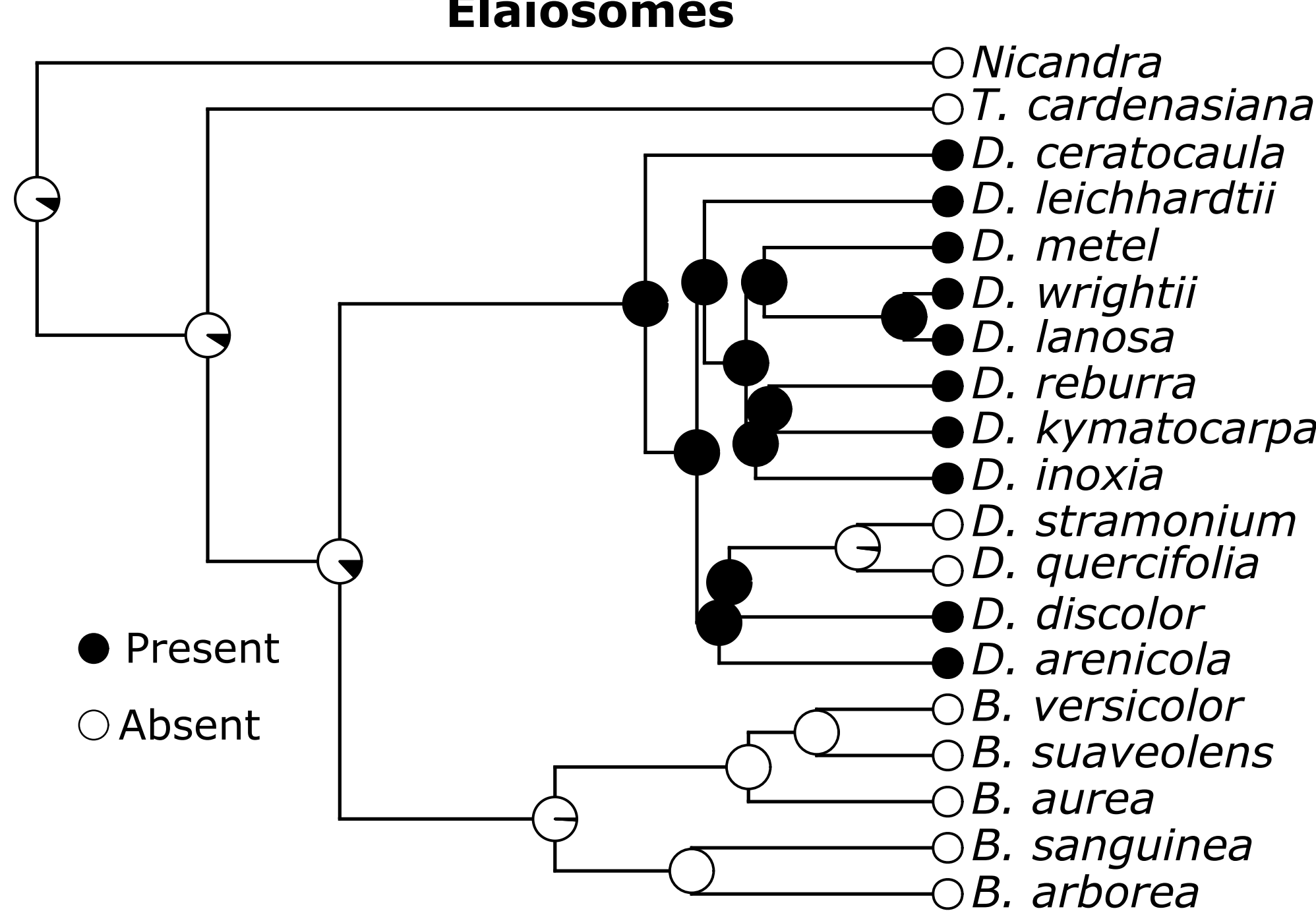

Mean $\mathrm{n}$ of transitions $\rightarrow \bigcirc 1.60(1.39,1.81)$ (95\% C.I.)

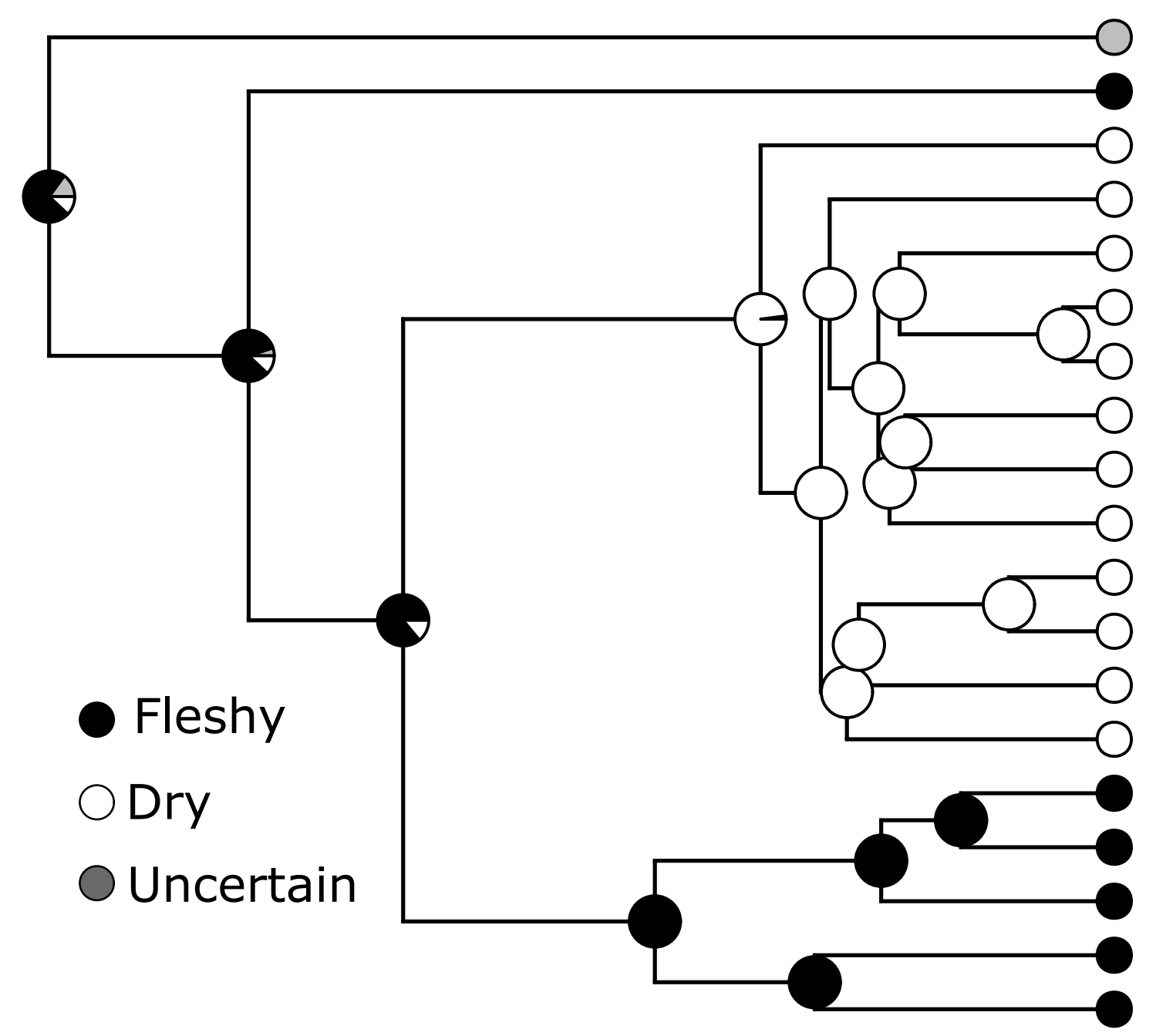

Mean $\mathrm{n}$ of transitions $\boldsymbol{0} \rightarrow 01.04(0.91,1.16)$ ( $95 \%$ C.I.)

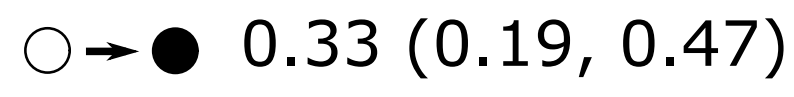

\section{Seed margin}

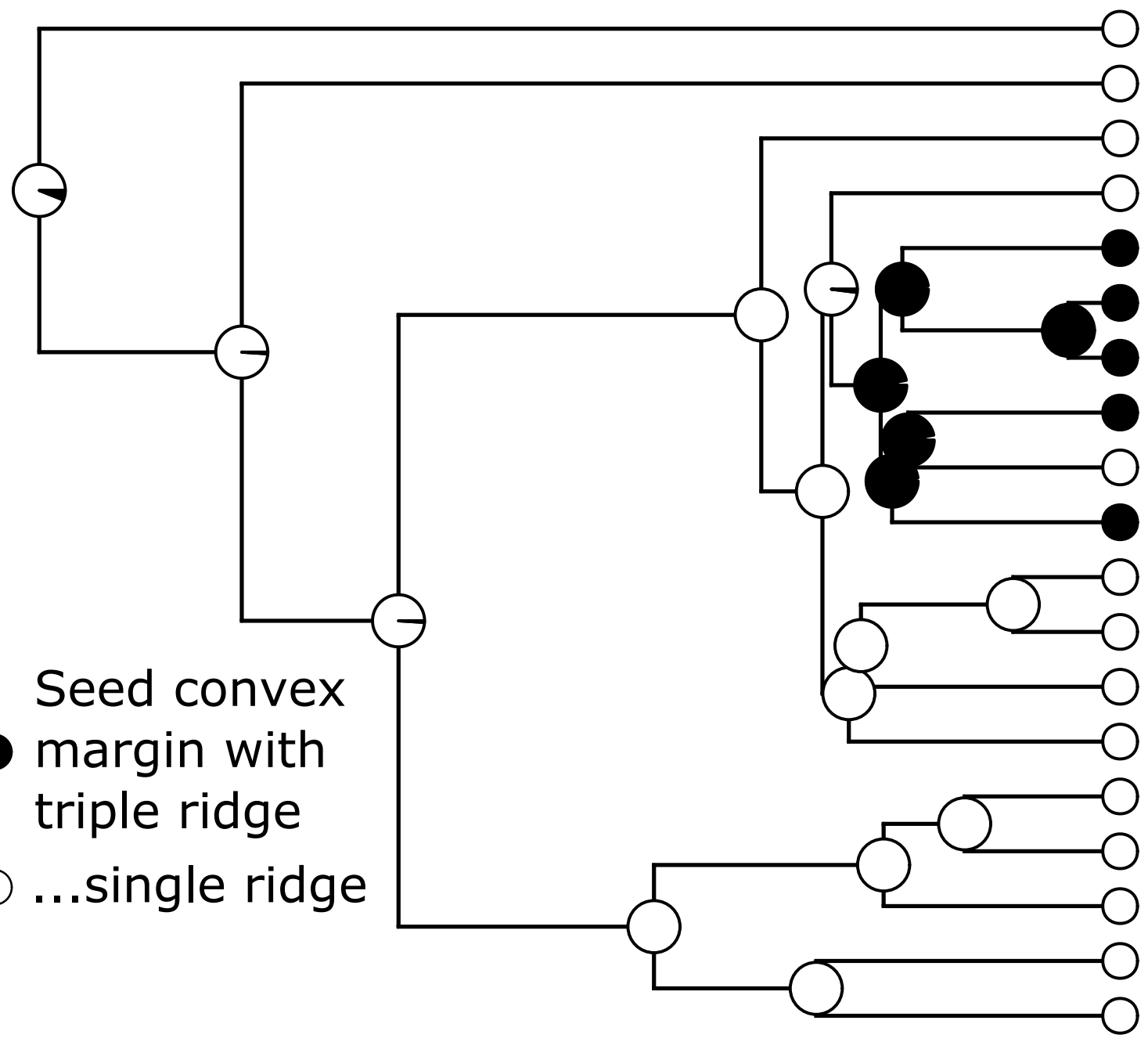

Mean $\mathrm{n}$ of transitions $\rightarrow \bigcirc 1.26(1.12,1.39)$ (95\% C.I.) $\bigcirc \rightarrow 01.20(1.09,1.31)$

\section{Fruit shape}

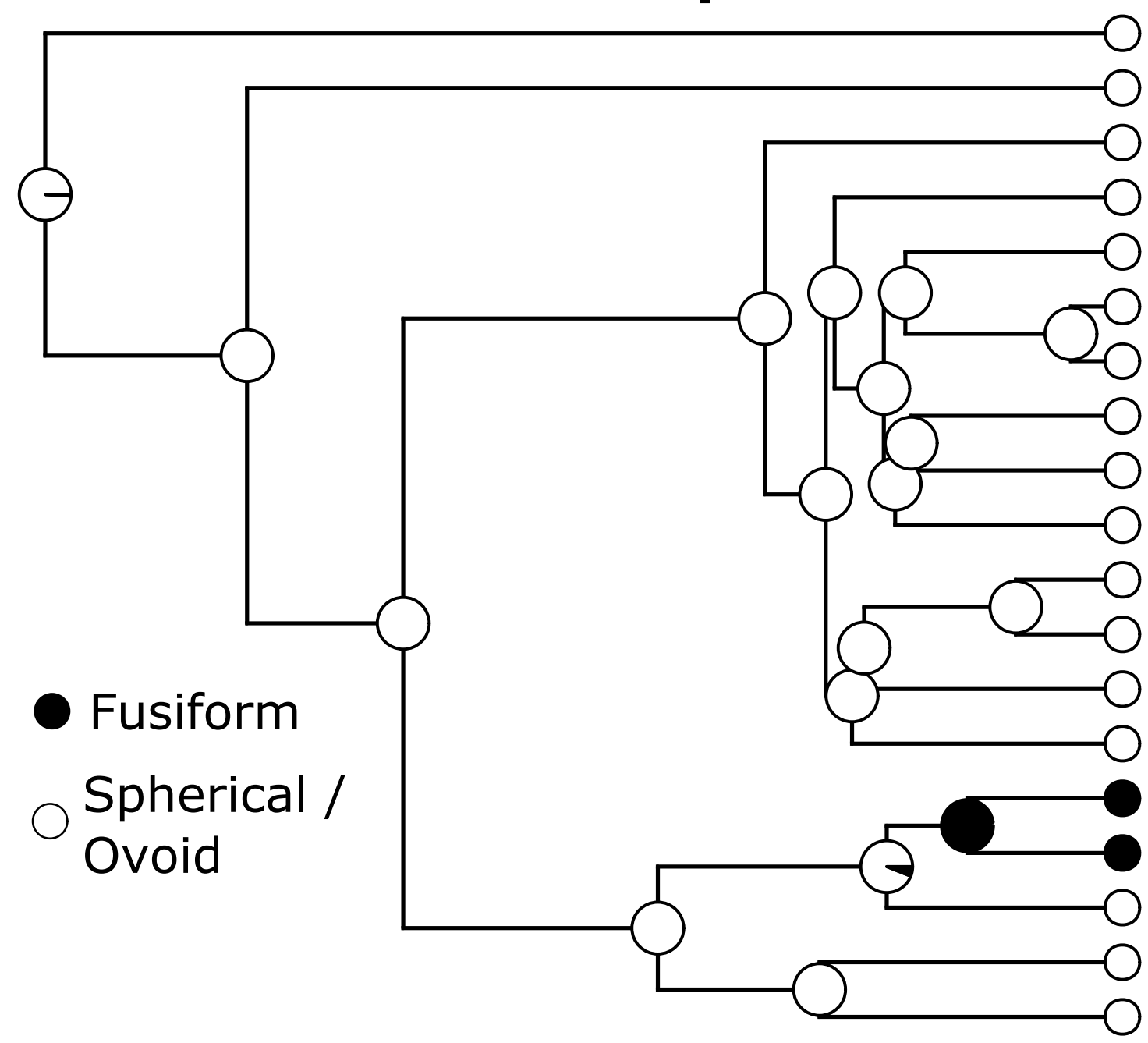

Mean $\mathrm{n}$ of transitions ( $95 \%$ C.I.)

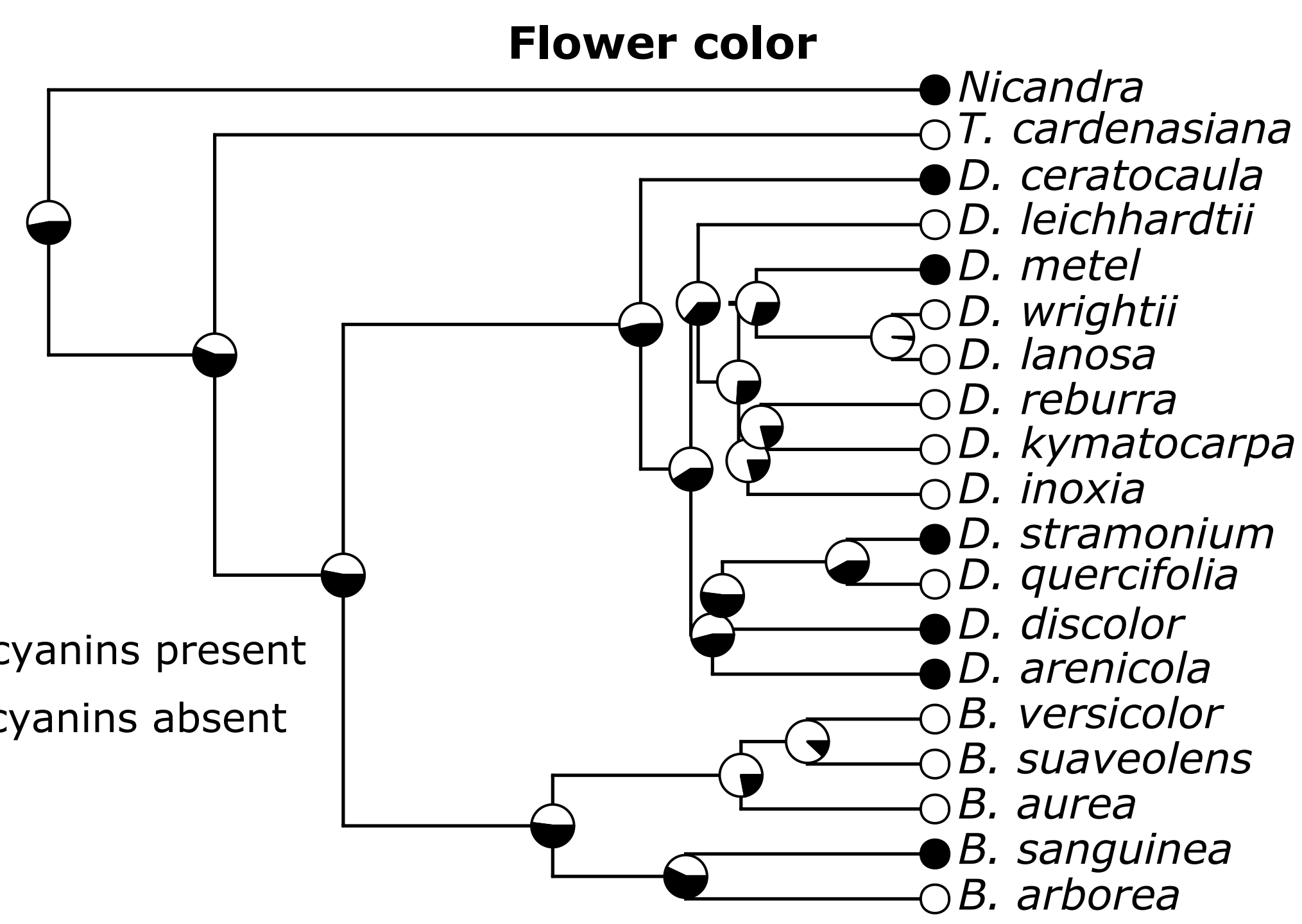

- Anthocyanins present Anthocyanins absent 
Figure 5

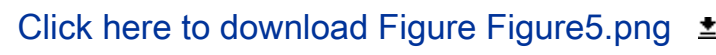

A

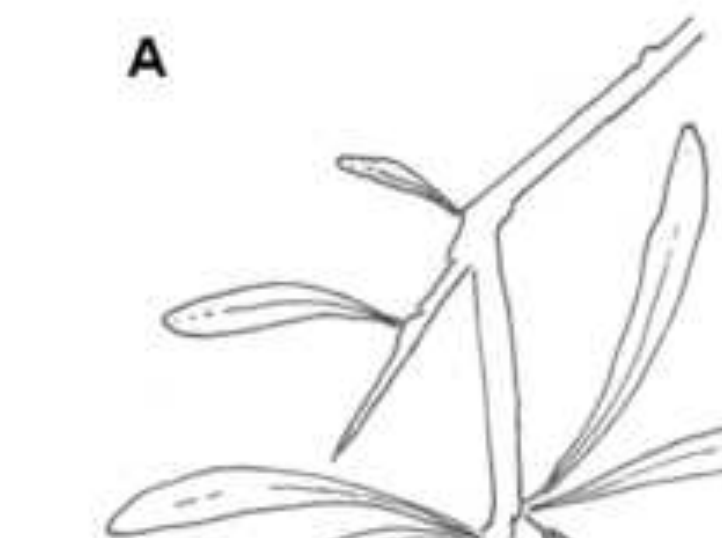

B

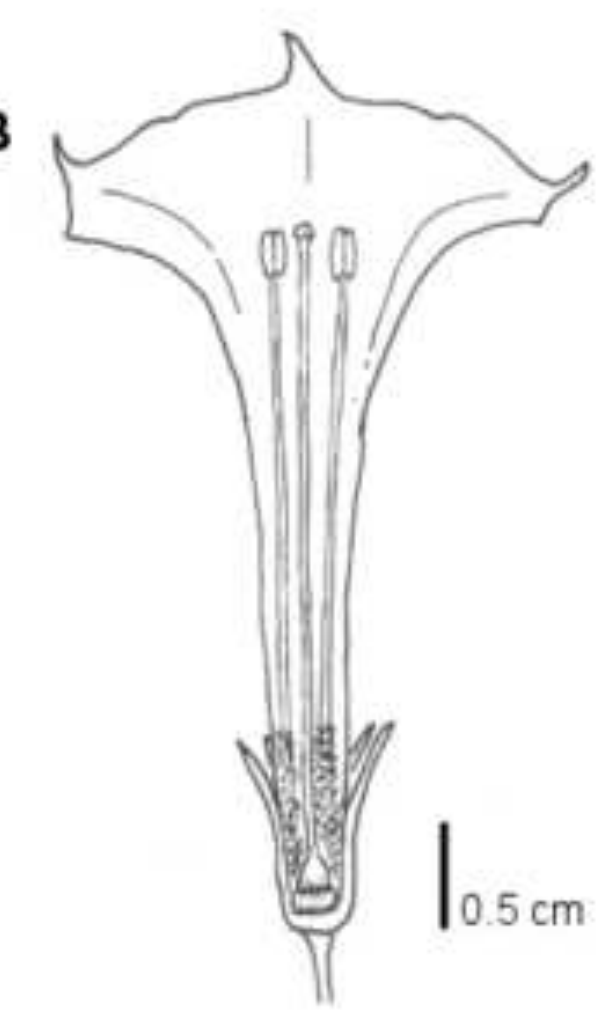

D

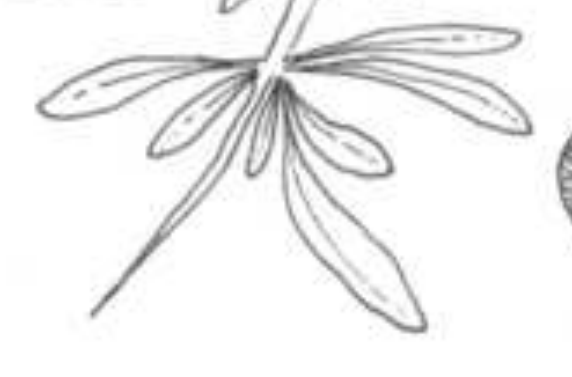

C
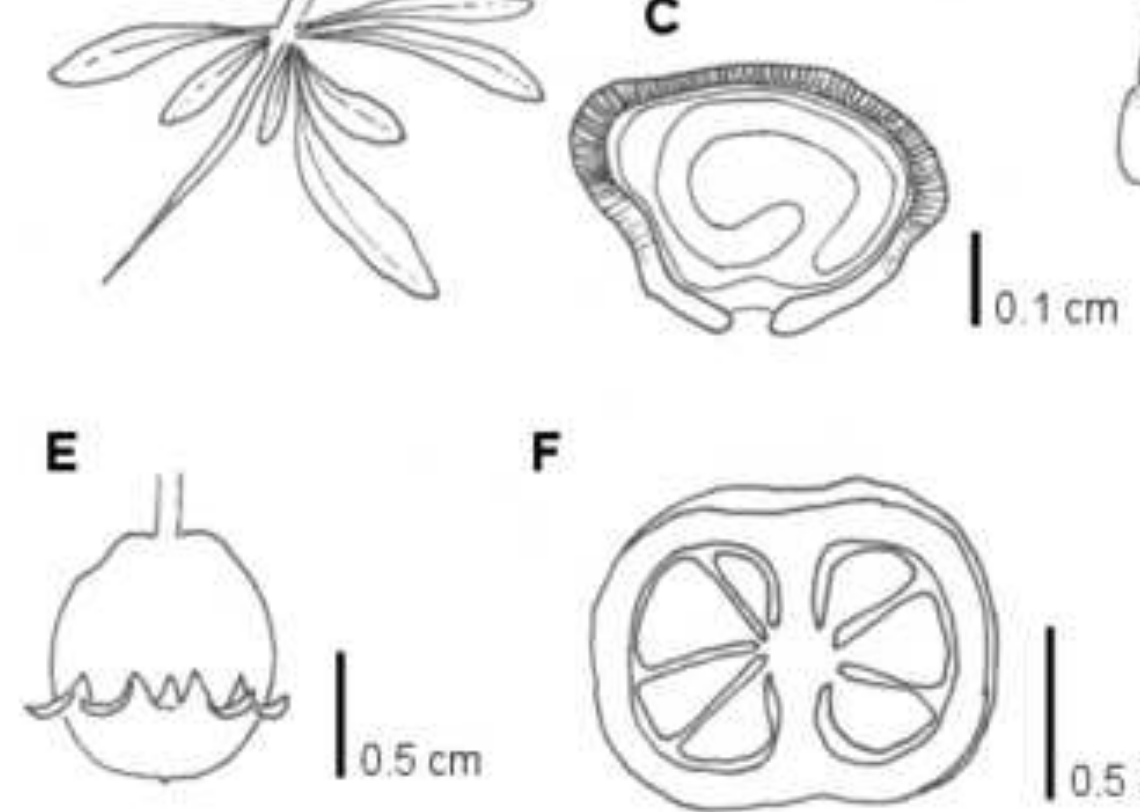

F

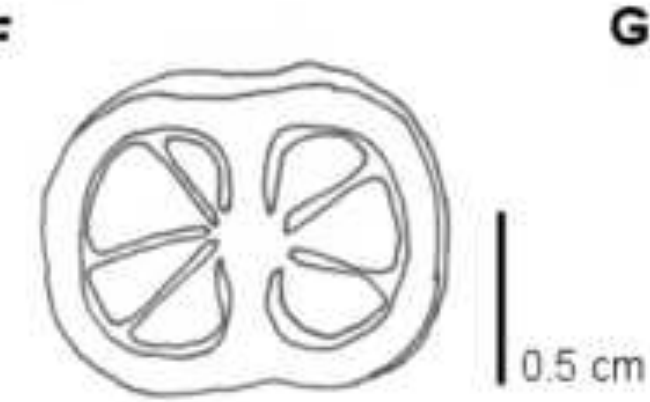

G
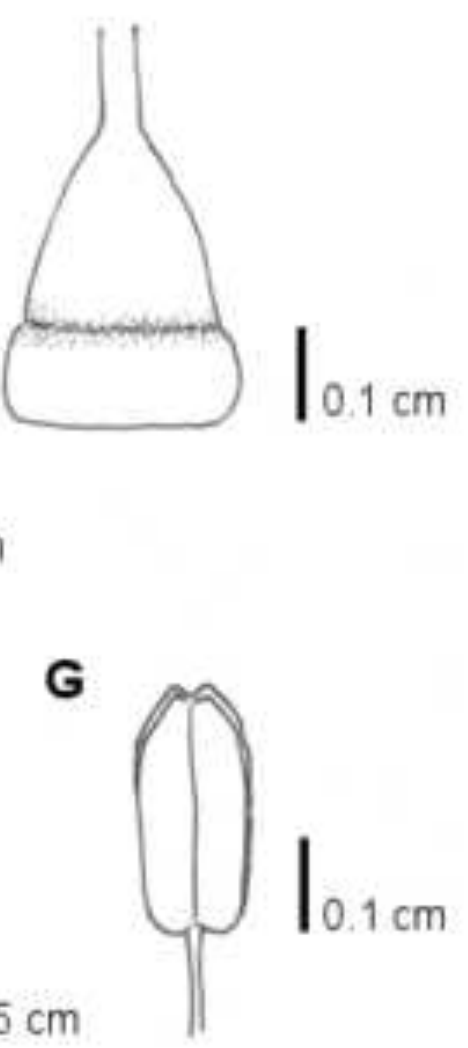


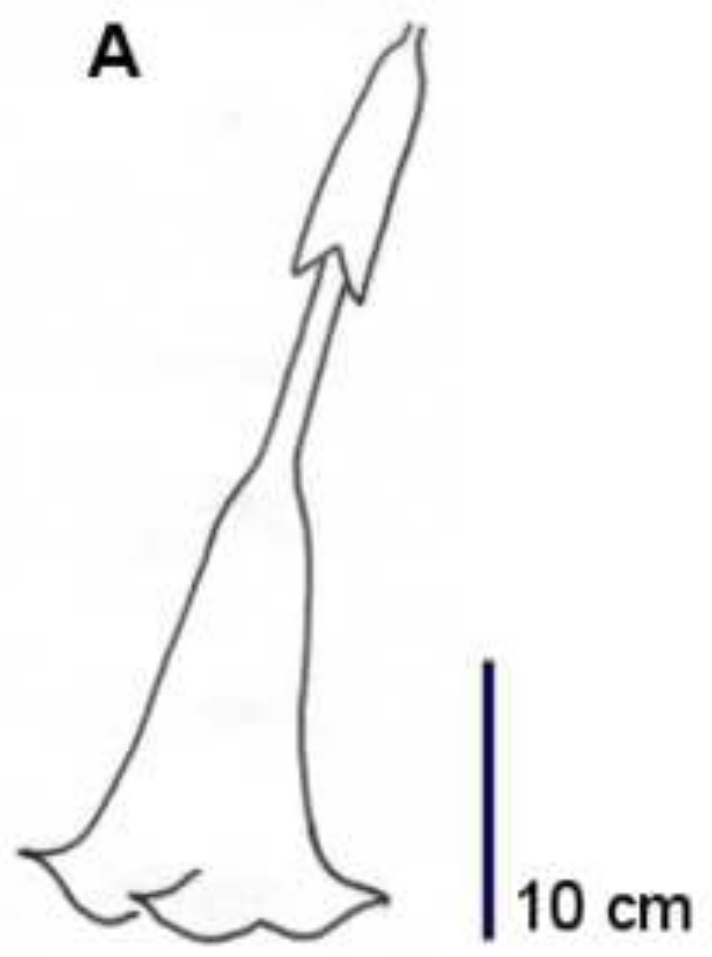

B

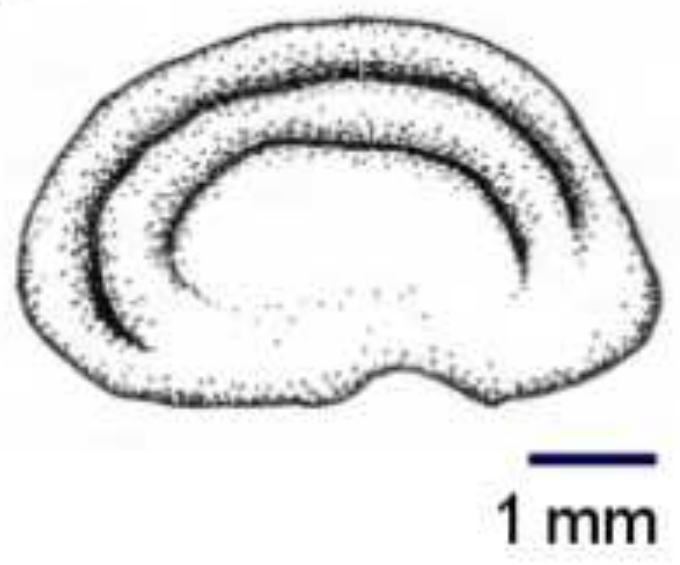

C

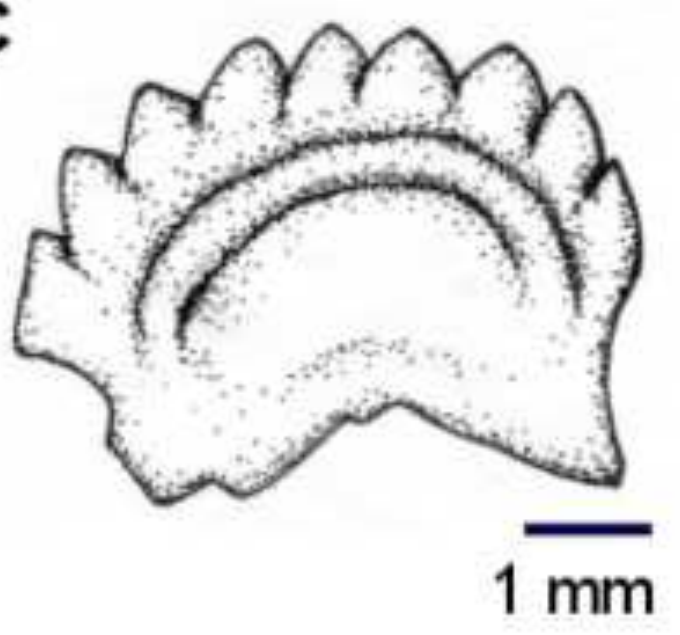



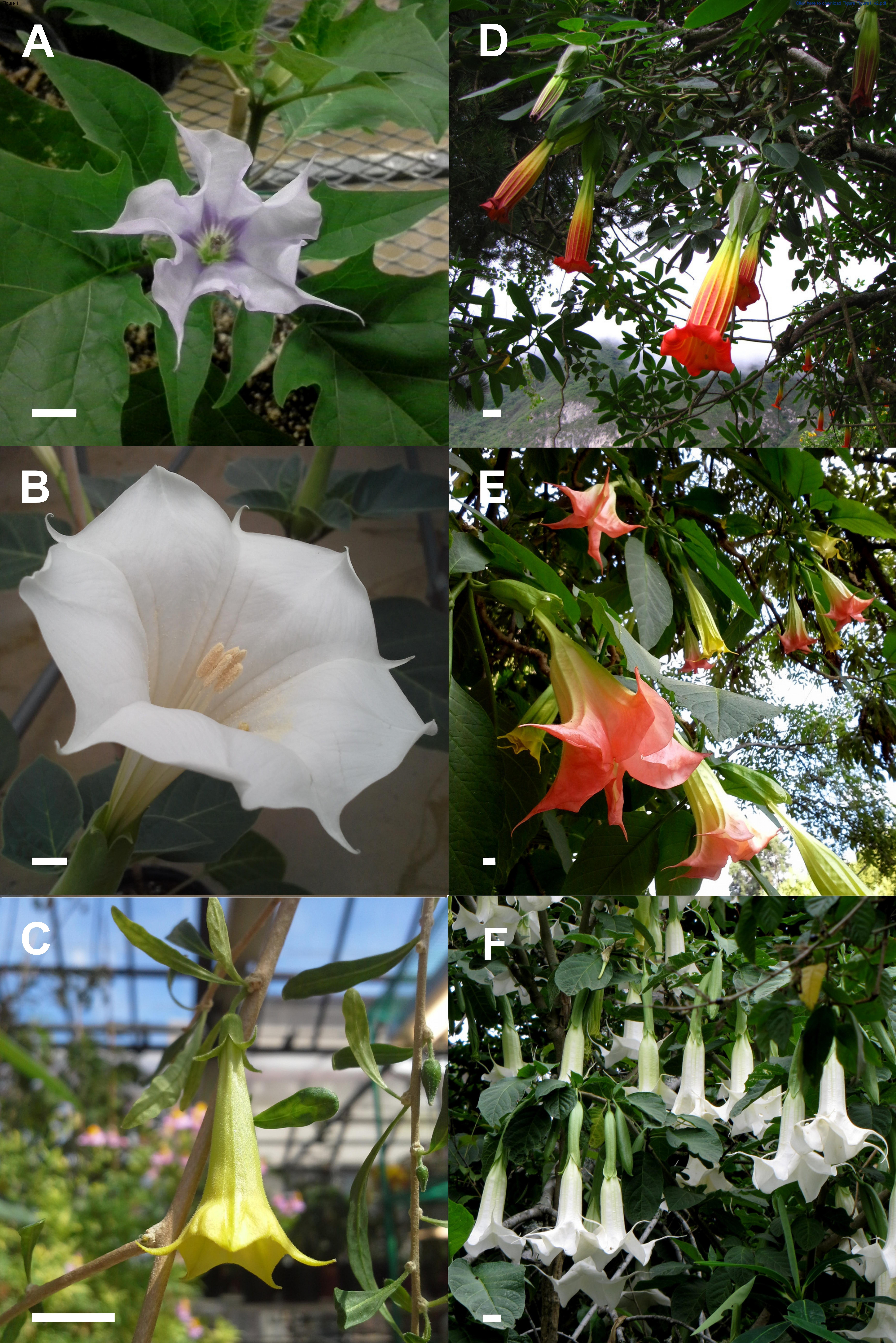
Table 1. Taxon list. All species in the ingroup are within Solanoideae. Subfamily and tribe are specified for each outgroup species.

\begin{tabular}{|c|c|}
\hline \multirow{18}{*}{ Ingroup } & Trompettia cardenasiana (Hunz.) J. Dupin \\
\hline & Brugmansia arborea (L.) Lagerh. \\
\hline & Brugmansia aurea Lagerh. \\
\hline & Brugmansia sanguinea (Ruiz \& Pav.) D. Don \\
\hline & Brugmansia suaveolens (Humb. \& Bonpl. ex Willd.) Sweet \\
\hline & Brugmansia versicolor Lagerh. \\
\hline & Datura arenicola Gentry ex Bye \& Luna-Cavazos \\
\hline & Datura ceratocaula Ortega \\
\hline & Datura discolor Bernh. \\
\hline & Datura inoxia Mill. \\
\hline & Datura kymatocarpa A.S. Barclay \\
\hline & Datura lanosa Barclay ex Bye \\
\hline & Datura leichhardtii spp. pruinosa (Greenm.) A.S. Barclay ex K. Hammer \\
\hline & Datura metel L. \\
\hline & Datura quercifolia Kunth \\
\hline & Datura reburra A.S. Barclay \\
\hline & Datura stramonium L. \\
\hline & Datura wrightii Regel \\
\hline \multirow{8}{*}{ Outgroups } & Solanoideae, Capsiceae - Capsicum lycianthoides Bitter \\
\hline & Solanoideae, Juanulloeae - Juanulloa speciosa Dunal \\
\hline & Solanoideae, Mandragora chinghaiensis Kuang \& A.M. Lu \\
\hline & Solanoideae, Lycieae - Lycium tenue Willd. \\
\hline & Solanoideae, Nicandreae - Nicandra phyalodes (L.) Gaertn. \\
\hline & Solanoideae, Physaleae - Physalis peruviana L. \\
\hline & Solanoideae, Solaneae - Solanum demissum Lindl. \\
\hline & Nicotianoideae - Nicotiana tabacum L. \\
\hline
\end{tabular}


Table 2. Properties of the nuclear regions used to estimate phylogenies for Datureae. Asterisk indicates the following: for our analysis of the combined dataset, we used partial sequences of lfy exons 2 and 3 for six outgroup species: J. speciosa, N. physalodes, N. tabacum, P. peruviana, $S$. demissum

\begin{tabular}{|c|c|c|c|c|c|c|c|}
\hline \multirow[t]{2}{*}{ Region } & \multicolumn{2}{|c|}{$\begin{array}{c}\text { Coverage (No. taxa } \\
\text { sequenced) }\end{array}$} & \multirow{2}{*}{$\begin{array}{c}\text { No. } \\
\text { characters }\end{array}$} & \multirow{2}{*}{$\begin{array}{l}\text { No. variable } \\
\text { characters }\end{array}$} & \multirow{2}{*}{$\begin{array}{c}\text { No. parsimony } \\
\text { informative } \\
\text { characters }\end{array}$} & \multirow[t]{2}{*}{ g1 statistic } & \multirow{2}{*}{$\begin{array}{c}\text { Best fitting } \\
\text { likelihood model }\end{array}$} \\
\hline & Ingroup & Outgroup & & & & & \\
\hline ITS & 18 & 9 & 813 & 273 & 141 & $-0.48^{a}$ & GTR+ \\
\hline lfy & 13 & $*$ & 1669 & 277 & 113 & $-1.26^{\mathrm{a}}$ & $\begin{array}{l}\text { exons: JC69 } \\
\text { intron: GTR+ } \\
\Gamma\end{array}$ \\
\hline waxy & 18 & 9 & 1451 & 477 & 161 & $-0.49^{a}$ & $\begin{array}{l}\text { exons: HKY85 } \\
\text { intron: HKY85 }\end{array}$ \\
\hline
\end{tabular}

${ }^{a}$ significant phylogenetic signal $(\mathrm{P}<0.001)$ according to the $\mathrm{g} 1$ statistic critical values (Hillis \& Huelsenbeck, 1992) 
1 Table 3. Comparison of morphological characters between Datura, Brugmansia and Trompettia

2 (see Lockwod, 1973 for earlier delimitation)

\begin{tabular}{|c|c|c|}
\hline Datura & Brugmansia & Trompettia \\
\hline \multicolumn{3}{|c|}{ Habit and Life history } \\
\hline Shrubs with large leaves & $\begin{array}{l}\text { Woody, arborescent shrubs or } \\
\text { small trees with large leaves }\end{array}$ & $\begin{array}{l}\text { Shrub with very small leaves } \\
\text { and old branches becoming } \\
\text { spines }\end{array}$ \\
\hline Annual (or bi-annual) & Perennial & Perennial \\
\hline \multicolumn{3}{|c|}{ Flower } \\
\hline Flower 5 to $18 \mathrm{~cm}$ & Flower 20 to $35 \mathrm{~cm}$ & Flower 2.5 to $3.5 \mathrm{~cm}$ \\
\hline Position erect or semi erect & Position pendant & Position pendant \\
\hline Anthesis one or two days & Anthesis several days & Anthesis several days \\
\hline $\begin{array}{l}\text { Flowering calyx not spathe- } \\
\text { like (except in } D . \text { ceratocaula), } \\
\text { calyx teeth usually separating } \\
\text { more or less equally }\end{array}$ & $\begin{array}{l}\text { Flowering calyx frequently } \\
\text { spathe-like or split along more } \\
\text { than one side, calyx teeth not } \\
\text { separating or splitting into two } \\
\text { groups }\end{array}$ & $\begin{array}{l}\text { Flowering calyx campanulate, } \\
\text { with teeth separating equally }\end{array}$ \\
\hline $\begin{array}{l}\text { Fruiting calyx circumscissile } \\
\text { near the base and falls away } \\
\text { with the corolla (except in } D \text {. } \\
\text { ceratocaula where it falls away } \\
\text { completely), the persistent base } \\
\text { forming a disk, cup or reflexed } \\
\text { frill subtending the mature fruit }\end{array}$ & $\begin{array}{l}\text { Fruiting calyx not } \\
\text { circumscissile, either falling } \\
\text { away entirely or forming a } \\
\text { persistent husk-like structure } \\
\text { around the mature fruit }\end{array}$ & $\begin{array}{l}\text { Fruiting calyx not } \\
\text { circumscissile, slightly } \\
\text { accrescent during fruit } \\
\text { maturation and eventually } \\
\text { splitting along a longitudinal } \\
\text { axis to expose mature fruit }\end{array}$ \\
\hline \multicolumn{3}{|c|}{ Fruit } \\
\hline $\begin{array}{l}\text { Fruit a capsule, round to ovoid, } \\
\text { borne on short pedicels in an } \\
\text { erect, sub-erect or nodding } \\
\text { position. }\end{array}$ & $\begin{array}{l}\text { Fruit a large, ovoid to } \\
\text { elongated, pendant berry borne } \\
\text { on much elongated pedicel }\end{array}$ & $\begin{array}{l}\text { Fruit a small, round, pendant } \\
\text { berry }\end{array}$ \\
\hline $\begin{array}{l}\text { Bicarpellate and tetralocular } \\
\text { due to presence of false septa. }\end{array}$ & Bicarpellate and bilocular & Bicarpellate and bilocular \\
\hline $\begin{array}{l}\text { Fruit regularly or irregularly } \\
\text { dehiscent }\end{array}$ & Fruit indehiscent & Fruit indehiscent \\
\hline $\begin{array}{l}\text { Pericarp usually spinose } \\
\text { (except in } D \text {. ceratocaula } \\
\text { where it is smooth) }\end{array}$ & Pericarp smooth and unarmed & Pericarp smooth and unarmed \\
\hline \multicolumn{3}{|c|}{ Seeds } \\
\hline $\begin{array}{l}\text { Seeds relatively small, discoid, } \\
\text { lacking a corky seed coat }\end{array}$ & $\begin{array}{l}\text { Seeds large, slightly } \\
\text { tetrahedral, with a thick, corky } \\
\text { seed coat }\end{array}$ & $\begin{array}{l}\text { Seeds relatively small, } \\
\text { tetrahedral, with a thin, corky } \\
\text { seed coat }\end{array}$ \\
\hline $\begin{array}{l}\text { Elaiosomes present in most } \\
\text { species }\end{array}$ & Elaiosomes not present & Elaiosomes not present \\
\hline
\end{tabular}


Appendix 1. Voucher information and genbank numbers. For each specimen we present the taxon name including authority; country; largest political subdivision (where applicable); collector(s) and collector number, herbarium code in parenthesis; and GenBank accession for DNA sequences of ITS; lfy; and waxy. A dash (-) indicates missing data.

Brugmansia arborea (L.) Lagerh.; -; Cultivated in Botanic Garden Munich, Germany; 2012/2883w7 (MSB); MG693004; MG693046; MG693065. Brugmansia arborea (L.) Lagerh.; Peru; Pasco; Smith 545 -; MG693005; MG693060; MG693064. Brugmansia aurea Lagerh.; Ecuador; Pichincha; Dupin 42 (QCA); MG693006; MG693047; MG693066. Brugmansia aurea Lagerh.; -; Cultivated in Botanic Garden Munich, Germany; 2012/2880w (MSB); MG693007; -; MG693067. Brugmansia sanguinea (Ruiz \& Pav.) D. Don; Ecuador; Pichincha; Dupin 43 (QCA); MG693008; MG693043; MG693068. Brugmansia sanguinea (Ruiz \& Pav.) D. Don; -; Cultivated in Botanic Garden Munich, Germany; 2012/2888 (MSB); MG693009; MG693061; MG693069. Brugmansia suaveolens (Humb. \& Bonpl. ex Willd.) Sweet; Costa Rica; San Jose; Dupin 2 (COLO); -; -; MG693070. Brugmansia suaveolens (Humb. \& Bonpl. ex Willd.) Sweet; -; Cultivated in Botanic Garden Munich, Germany; 2012/2889 (MSB); MG693010; -; MG693071. Brugmansia versicolor Lagerh.; Ecuador; Cultivated in Huntington Botanical Gardens, CA; 43862 (HNT); MG693011; -; MG693072. Brugmansia versicolor Lagerh.; -; Cultivated in Botanic Garden Munich, Germany; 2012/2890 (MSB); -; -; MG693073. Datura arenicola Gentry ex Bye \& Luna-Cavazos; Mexico; Baja California Sur; H.S. Gentry 7881 (RSA); MG693012; MG693057; MG693074. Datura ceratocaula Ortega; Mexico; Jalisco; Dupin 50 (COLO); MG693013; MG693055; MG693075. Datura ceratocaula Ortega; Mexico; Jalisco; Dupin 51 (COLO); MG693014; MG693056; MG693076. Datura ceratocaula Ortega; Mexico; Hidalgo; A. Ventura A. 91 (WIS); MG693016; -; MG693078. Datura ceratocaula Ortega; Mexico; Durango; Wieder, Bennett, Dunn \& Torke 208 (WIS); MG693015; -; MG693077. Datura discolor Bernh.; USA; California; S.D. White 11262 (RSA); MG693017; MG693054; MG693079. Datura inoxia Mill.; USA; California; M. DeDecker 2669 (RSA); MG693018; -; MG693080. Datura inoxia Mill.; Mexico; Jalisco; Dupin 52 (COLO); MG693019; MG693058; MG693081. Datura kymatocarpa A.S. Barclay; Mexico; Michoacan; J.M. Porter \& V.W. Steinmann 14726 (RSA); MG693021; MG693042; MG693082. Datura kymatocarpa A.S. Barclay; Mexico; Guerrero; Jorge Calonico Soto 14914 (MEXU); MG693020; -; -. Datura lanosa Barclay ex Bye; Mexico; Sonora; A.L. Reina G 96-542 (RSA); MG693024; -; -. Datura lanosa Barclay ex Bye; Mexico; Chihuahua; Robert Bye \& Edelmira Linares 14252 (MEXU); MG693022; -; MG693083. Datura lanosa Barclay ex Bye; Mexico; Sonora; Robert Bye 28391 (MEXU); MG693023; -; MG693084. Datura leichhardtii ssp. pruinosa (Greenm.) A.S. Barclay ex K. Hammer; Mexico; Puebla; Dupin 38 (COLO); MG693026; MG693053; MG693085. Datura leichhardtii ssp. pruinosa (Greenm.) A.S. Barclay ex K. Hammer; Mexico; Oaxaca; Robert Bye \& L. Cervantes (MEXU); MG693025; -; -. Datura leichhardtii ssp. pruinosa (Greenm.) A.S. Barclay ex K. Hammer; Mexico; Oaxaca; A. Mendoza (WIS); MG693027; -; MG693086. Datura metel L.; Mexico; Michoacan; Jose C. Soto Nunez, Amada Roman de Soto y Fernando Soto R. 7080 (MEXU); MG693029; -; MG693088. Datura metel L.; Mexico; Mexico; Robert Bye 26964 (MEXU); MG693028; -; MG693087. Datura quercifolia Kunth; USA; California; A.C. Sanders 5337 (RSA); MG693036; -; MG693092. Datura quercifolia Kunth; Mexico; Aguascalientes; Gerardo Garcia R. 5004 (MEXU); MG693034; MG693044; MG693090. Datura quercifolia Kunth; Mexico; Guanajuato; Esteban Martinez 39665 (MEXU); MG693035; MG693045; MG693091. Datura quercifolia Kunth; Mexico; -; Dupin 53 (COLO); MG693033; MG693051; MG693089. Datura reburra A.S. Barclay; Mexico; Sonora; Gentry, Barclay\& Arguelles 19249 (COLO); MG693030; -; -. Datura reburra A.S. Barclay; Mexico; Sinaloa; Gentry, Barclay\& Arguelles 19442 (COLO); MG693031; -; -. Datura reburra A.S. Barclay; Mexico; Sinaloa; B. Templeton 7079 (RSA); MG693032; -; MG693093. Datura 
stramonium L.; USA; California; B. Ertter 8885 (RSA); MG693038; -; MG693095. Datura stramonium L.; USA; Kansas; Dupin 54 (COLO); MG693037; MG693052; MG693094. Datura wrightii Regel; USA; Nebraska; Dupin 35 (COLO); MG693039; MG693050; MG693096. Datura wrightii Regel; USA; Arizona; Dupin 48 (COLO); MG693040; MG693049; MG693097. Datura wrightii Regel; USA; Utah; Dupin 49 (COLO); MG693041; MG693048; MG693098. Trompettia cardenasiana (Hunziker) J. Dupin; Bolivia; Potosi; Smith 384 (WIS); MG693003; MG693059; MG693063. Trompettia cardenasiana (Hunziker) J. Dupin; Bolivia; Potosi; Smith 385 (WIS); DQ314156.1; DQ309516.1; DQ309466.1. Nicandra physalodes (L.) Gaertn.; Peru; Cultivated in Beal Botanical Garden, Michigan State University; Olmstead S-38 (WTU); MG693002; -;

MG693062. Capsicum lycianthoides Bitter; Ecuador; Pichincha; Smith 203 (WIS); DQ314158.1; ; DQ309468.1. Juanulloa speciosa (Miers) Dunal; Colombia; Tolima; J. Ng 023 (COLO);

KP100294.1; -; KR083044.1. Lycium tenue Willd.; South Africa; Western Cape; Olmstead 99-13 (WTU); GQ301198.1; -; DQ124542.1. Mandragora chinghaiensis Kuang \& A.M. Lu; China; Qinghai; Z.Y. Zhang 089 (HNWP); -; -; DQ069264.1. Mandragora chinghaiensis Kuang \& A.M. Lu; China; Qinghai; T. Tu Tu521-1 -; JX067491.1; -; -. Physalis peruviana L.; Ecuador; Pichincha; Smith 217 (WIS); DQ314161.1; DQ301514.1; DQ309471.1. Solanum demissum Lindl.; -; -; - (PI545757); AY875794.1; DQ266894.1; AY875446.1. Nicotiana tabacum L.; -; -; - -; AYMY00000000.1. 
1 Appendix 2. Ify primers designed for this study

2

\begin{tabular}{|l|l|}
\hline Primer name & Sequence 5' - $^{\prime}{ }^{\prime}$ \\
\hline LFYDatF1 & GATTACTTGTTCATCTCTATGAGCAATGC \\
\hline LFYDatF2 & AGGGAGCATCCGTTTATCGTGACG \\
\hline LFYDatF3 & TATCAACGAGGGCGGAGGAGGAGGAGTAAGC \\
\hline LFYDatF4 & AGGAGGACGATGAAACGGAGGAATTAGG \\
\hline LFYDatF5 & GGAAATAATGGTGAGAGGAAGAAGGC \\
\hline LFYDatR1 & GTTTATGTAGCTTGCCCCTGCCTTCTTCGCG \\
\hline LFYDatR2 & GGAGCCATCCTCGTCAAGACAATGAAGTGCG \\
\hline LFYDatR3 & CCTTGTCGAGCAGCTATGGCTACCAGGGGC \\
\hline LFYDatR4 & ACTGCAAAACTGAACCTGAGTCG \\
\hline LFYDatR5 & AACACAATCAGACTAACCATCCAACGC \\
\hline LFYDatRi6 & TTGAGTGGAAGTACAAATGGAGTAATGGGC \\
\hline
\end{tabular}

3

4 All primers with an $\mathrm{F}$ (forward) in the name are placed on the exon 2 of lfy, the ones with an $\mathrm{R}$ 5 (reverse) are found on the exon 3; and the one with Ri (reverse, internal) is placed on the intron II. 
1 Appendix 3. starBEAST2 analysis of Datura (showing only results for the ingroup). Nodes with an 2 asterisk have a pp of 1.00 .

3

4

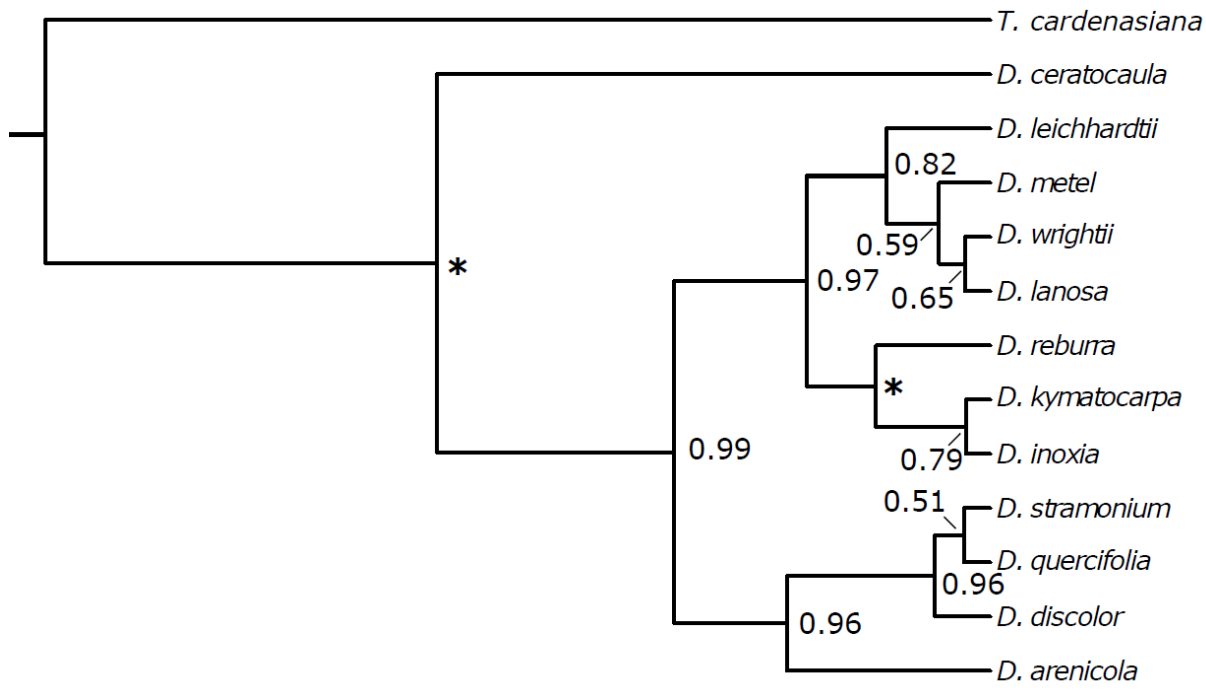

6 
1 Appendix 4. Divergence times with confidence intervals for Datureae and outgroups.

\begin{tabular}{|l|l|l|}
\hline MRCA $^{(1)}$ & Median age (Ma) & 95\% CI (Ma) \\
\hline Brugmansia & 18.4 & $27.5,10.8$ \\
\hline Brugmansia arborea + B. sanguinea & 12.0 & $20.2,5.1$ \\
\hline Brugmansia aurea + B. suaveolens & 9.3 & $15.7,4.4$ \\
\hline Datura & 14.2 & $20.6,8.8$ \\
\hline Datura arenicola + D. stramonium & 11.4 & $16.1,6.4$ \\
\hline Datura kymatocarpa + D. leichhardtii & 10.7 & $16.6,7.1$ \\
\hline Datura + Brugmansia & 28.5 & $39.2,18.7$ \\
\hline Datureae & 34.7 & $46.9,23.8$ \\
\hline Datureae + Nicandra & 42.7 & $55.5,30.6$ \\
\hline Solanoideae & 54.1 & $67.4,52.2$ \\
\hline
\end{tabular}

${ }^{(1)}$ Most Recent Common Ancestor 
1 Appendix 5. Short branches (arrows) in Trompettia cardenasiana
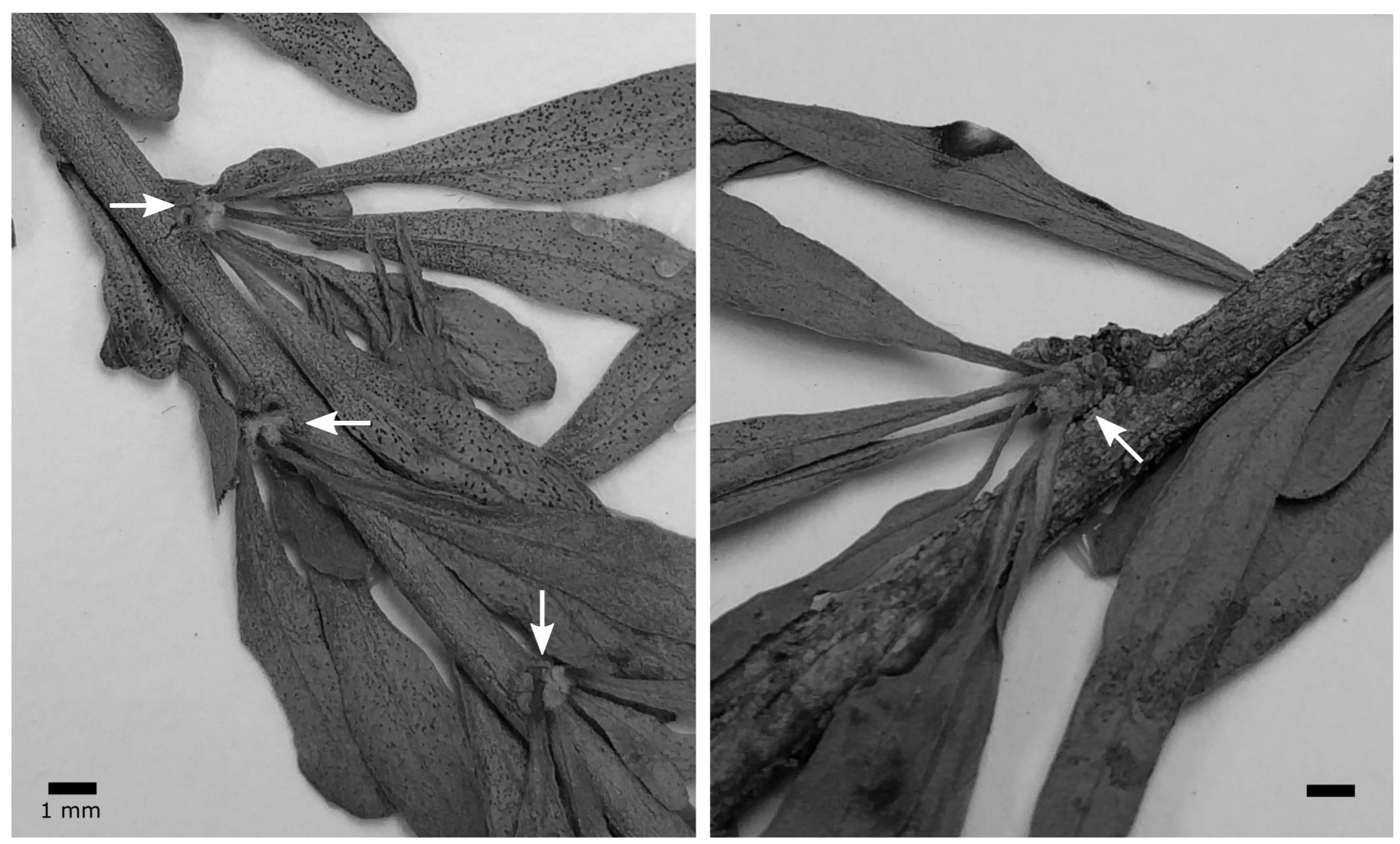